\title{
ARTIGOS
}

\section{HISTÓRIA DA PALESTINA NOS TEMPOS DO NOVO TESTAMENTO (IV).}

\section{(Continuação) .}

\section{§ 3. - A posição jurídica de Herodes. Extensão e limites de seu poder.}

220. - O segundo período de reinado de Herodes, isto é, o segundo decênio e o comêço do terceiro de seu govêrno (c. 28/27-c. $14 / 13$ a. C.), é, inegàvelmente, o período do áuge de seu poder, período que certamente foi de esplendor e que justifica, até certo ponto, o fato de se lhe dar comumente o nome de Grande (1). Por outro lado, designando êste período como o período do auge do poder de Herodes, é preciso ter sempre diante dos olhos o fato de que êste apogeu de seu poder era apenas o máximo dos poderes que Roma the concedia, e, assim mesmo, êste máximo estava sujeito às imudanças que convinham aos interêsses de Roma. Faltava, com efeito, a Herodes aquilo que nos parece essencial em um chefe de estado absoluto: a soberania perfeita. Chegou-se a dizer que Herodes, em última análise, nada mais era senão um procurador de Augusto, com o título de rei (2). De fato, se êle, como rei aliado dos romanos, estava isento de pagar tributo a Roma (n. 234), compensava êle esta isenção por meio de abundantes presentes a Augusto, e à sua família, e por meio de somas fabulosas, gastas em construções magníficas pelo Império afora. Se tinha certos privilégios, que um procurador não tinha, êstes lhe podiam ser tirados a qualquer momento, e certos dêstes privilégios lhe foram, de fato, tirados, ao 'menos em parte.

221. - Diante disto, deveremos estudar, em primeiro lugar, a condição jurídica de Herodes e da Judéia dentro da organização do Império romano em geral, e perante a pessoa de Augusto em particular, examinando, ainda, as conseqüências

(1).. - A. H. M. Jones 62 dá ao capítulo, em que descreve êste periodo do govêrno de Herodes, o título de: Herod the Great. Veremos a seu tempo, em que sentido, e até que ponto, êste título 'se justifica.

(2). - J. Marquardt, citado por U. Holzmeister $3^{3}$; cf. J. Felten 1, 148. A posição dos reis aliados, ainda em tempos da república, é definida bem, diante do Senado, por Aderbal, filho de Micipsa, rei da Numídia, em Sakústio, Bellum Jugurthinum 14, 1: Patres conscripti, Micipsa pater meus moriens mihi praecepit, uti regni Numidiae tantummodo procurationem existumarera meam, caeterum jus et imperium ejus penes vos esse. 
desta posição em sua parte positiva e negativa, isto é, os direitos que Herodes tinha como rei aliado, e as limitações de sua soberania, impostas por Roma. Perfeitamente cônscio de sua inteira dependência de Roma, procurava êle, por todos os meios, continuar nas boas graças dela, seja pelo cumprimento escrupuloso de seus deveres para com o Império, seja por meio de abundantes demonstrações de sua boa vontade, demonstraçōes que, muitas vêzes, tocavam às raias do servilismo. Roma, por seu lado, recompensava seus serviços, tanto por meio do aumento de seus territórios, quanto por meio de outros favores, contanto que isto conviesse a seus interêsses, e justificasse a demonstração gradual da utilidade de Herodes no desempênho de suas funções como rei aliado, e, ainda, - exigisse a situação das províncias. Deverão estudar-se igualmente as realizações positivas do reinado de Herodes, sua posição diante da lei judaica, e suas relações com o povo judaico em geral (cf. n. 219). Com efeito, se Herodes era o mais brilhante dos reis helenísticos vassalos de Roma - como, aliás, também o mais conhecido de entre êles (n. 30) -, era, contudo, rei dos judeus, rei, por conseguinte, que se via a todo o passo embaraçado em suas realizações pelos costumes judaicos, e o caráter peculiar de seu povo (3), ao qual, todavia, êle mesmo se impôs pela astúcia e a violência.

222. - I. Herodes, rei aliado He Roma. - Nicolau de Damasco (n. 54), em sua defesa, perante Augusto, do último tes-

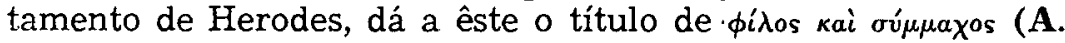
$17,9,6 \S 246$ ), título que corresponde ao latino socius et amicus populi Romani. Parece provável que êste título exprimisse a condição jurídica de Herodes de fato, ainda que, talvez, não a definisse de direito em sentido estrito (4). Suetônio, com efeito, distingue expressamente entre os reinos conquistados por Augusto pelo direito da guerra, reinos que êle restituia aos reis anteriores, ou dava a estrangeiros, e os reges socii, isto é, cs reis que se haviam aliado voluntàriamente ao povo romano por meio de um foedus formal, se bem que por meio de um foedus non aequum (5). Assim mesmo, porém, o título de rex socius era muitíssimo cobiçado, e, às vêzes, bem pago, pe-

(3). - M.J.-Lagrange 176.

(4). - Cf. W. Otto 54; M.-J. Lagrange 176; A. H. M. Jones 62; U. Holzmeister 33. Com o crescer do poderio romano diminuiu a admissão de cłdades e reinos a urn foedus aeqưrm; ef. Estrlabāo. Geographica 17, 3, 24 (p. 839). Agripa I foi admitido a um foedus formal por Cláadio (A. 19, 5, $1 \S 275$ ), mas é pouco provável quei se tratasse, realmente, de um foedus aequrum.

(5). - Suetônio, Augustưs 48; cf. U. Holzmeister 33. 
los reis estrangeiros, em parte por causa da garantia que êle lhes oferecia com relação a seus inimigos, efetivos ou potenciais, em parte pelo fato de prevenir uma próxima anexação e assimilação de seus reinos pelo próprio Império (6) .

223. - E' verdade que Judas Macabeu, em 161 a. C., havia pedido e obtido, aequo foedere, uma aliança com os romanos

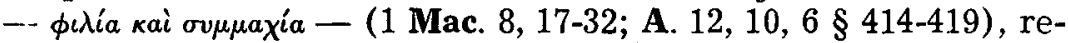
novada no trmpo de Jonatã (1 Mac. 12, 1-4; A. 13, 5, 8 § 163165), de Simão (1 Mac. 14, 16-19, 24; 15, 15-21; A. 13, 7, 3 § 227), de João (Hircano (A. 13, 9, 2 § 259-264), e de Alexandre Janeu (7), mas esta aliança podia dizer-se dissolvida, por parte dos judeus, em virtude dos acontecimentos que se deram por ocasião da campanha de Pompeu na Palestina (n. 13s). Um decreto

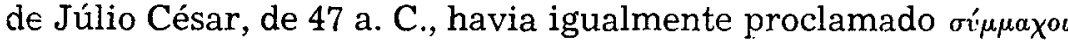
e pídoc seus, a Hircano II e seus decendentes (A. 14, 10, $2 \S 194$ e 3 § 197), mas, não sendo Herodes descendente de Hircano II, esta informação de José, tão pouco quanto as anteriores, pode aduzir-se, para provar, que fôsse um rex socius de direito e aequo foedere (8) .

224. - A narração de José exclui, aliás, positivamente um foedus aequum no caso de Herodes. Em 40 a. C., êste, a quem. faltava qualquer título para isto (9), foi nomeado rei por um senatus-consulto, por recomendação de Marco Antônio e de Otaviano (nn. 138-141). Tratava-se, por conseguinte, de uma simples nomeação, por via administrativa comum (10). Como houvesse tropas de Herodes combatendo no exército de Marco Antônio em Áccio (n. 194), podia êle considerar-se como um dos

(6). - Veja-se o exemplo de Ptolomeu XIII, citado por Suetônio, Caesar 54: Societates ac regna pretio dedit, ut qui toi Ptolentaeo prope sex millia talentorum: suo Polmpeique nomine abstulerit; cf. Plutarco, Caesar 48. - Seis mil talentos áticos de prata, a 6.000 dracmas ou denários cada um, equivaliam a 36 milhōes de dracmas, ou 144 milhões de sestércios. - J. Juster 1, 215 define bem a situação, quando diz que os países $e$ as cidadies cachaient leur dépendance de Rome sous le titre d'alliés.

(7). - Estrabão, citado em A. 14, 3, $1 \S 35$, onde deve entender-se Alexandre Janeu, em lugar đe Aristóbulo II; ef. J. Juster 1, 216 . Ver também Ap. $2,11 \S 134$ : Quando os romanos declararam guerra a todos os 'reis do mundo. sòmente os nossos, em virtude de sua fildelidade, continuaram alizados e amigos seus. - Sôbre estas alianças em geral veja-se Justino, Epitoma Historiarum Philippiaarum 36, 3. 9: A Demetrio cum descivissent, amicitia Romanorum petita primi omnium ex Orientalibus libertatem acceperunt, facile tunc Romanis de alienis largientibus. - Sôbre as diversas alianças, em particular, vejam-se, por exemplo, G. Ricciotti 299-301. 316s. 324-326. 333; F.-M. Abel Les livres des Maccabées, Paris 1949, 152-157. 200. 266-269.

(8). - U. Holzmeister 33 .

(9). - F.-M. Abel 1, 361 .

(10). - W. Otto 55 . 
reis vencidos por Otaviano, aos quais êste, conforme Suetônio, restituiu o reino perdido pelo direito da guerra (n. 222). Enfim, de qualquer modo que fôsse, estivera Herodes, como rei vassalo, do lado de Marco Antônio vencido. Em Rodes, em 30 a. C., Herodes foi novamente confirmado rei por Otaviano, e por um posterior senatus-consulto (n. 205), e José nos diz expressamente, que foi confirmado rei por doação de César, e decreto dos

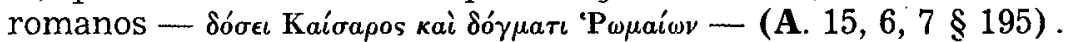
Juridicamente, por conseguinte, era êle, depois de Accio, um rex restitutus. Fora talvez dos sacrifícios celebrados por ocasião da nomeação de Herodes em 40 a. C. (n. 139), não há nenhum indicio em José, em ambas as nomeações de Herodes, de um foedus pròpriamente dito, que é essencialmente um contrato bilateral, ainda quando se trata de um foedus non aequum (11). Se, na primeira nomeação, Herodes não tinha título algum para servir de parceiro numa aliança com Roma, igualmente não o tinha por ocasião de sua confirmação por parte de Otaviano, uma vez que êle mesmo se considerava deposto pelo próprio fato da derrota de Marco Antônio (n. 204). Declara-o êle mesmo em seu discurso diante de Otaviano (G. 1, 20, $1 \S 390$ ), e confirma suas palavras pelo gesto, aparecendo diante do vencedor de Áccio sem o seu diadema (ib. § 387; A. 15, 6, i6 § 187). Na prática, porém, pode dizer-se que a afirmação de Nicolau de Damasco corresponde à verdade, enquanto Herodes em tudo era tratado como os restantes reges socii, e parece mesmo que possuisse certos privilégios, que, em geral, não se concediam a tais reis. De resto, Nicolau não daria a Herodes êste título diante do próprio Augusto, se êle não fizesse jus àquêle!título, ao menos de fato (12).

225. - Um rex socius, com efeito, que sempre dependia diretamente do imperador (13), só podia usar êste título, e exercer a autoridade correspondente, com a aprovação do impera-

(11). - W. Otto 55; M.-J. Lagrange 177; J. Felten 1, 148; U. Holzmeister 32s; F.M. Abel 1, 361. - J. Juster $1,217^{2}$ insiste, pelo contrário, no conceito de alianda entre Rorua, Hexodes e os outros príncipes herodianos.

(12). $\rightarrow$ W. Otto 54 .

(13). - Estrabão, Geographịca 17, 3, 25 (p. 840); cf. 11, 14, 15 (p. 532) sôbre os reis da Armênia. Entende-se esta dependência, diante do sistema de divisão das províncias em senatoriais e imperiais, sendo as últimis aquelas que aindia não estavam perfeitamente assimiladas, ou lse encontravam na periferia do Impéria, necessitadas, por conseguinte, de guarniçōes permanentes; cf. Estrabão, ib. 17, 3, 25 (p. 840); Cássio Dión. Historia Romana 53, 12. 1.3 e 7 . 
dor, com, ou sem a confirmação pelo Senado (14) o o título, "em geral, só se concedia a príncipes, que tinham debaixo de si um território bastante considerável, devendo os outros contentar-se com os títulos inferiores de etnarcas, tetrarcas, e outros (15). Além disso, concedia-se, por via de regra, ao indivíduo, cessando com a sua morte. Monarquias hereditárias em geral não se admitiam (16). Os filhos, nomeados sucessores por seus pais, careciam, por conseguinte, da confirmação do imperador, confirmação que podia ser negada, e, mesmo quando confirmados, recebiam muitas vêzes territórios cerceados, e um título inferior. Por vêzes, os territórios em questão concediam-se a outros, como nos informa Suetônio (n. 222), quando 'não se transformavam, de vez, em províncias romanas. Todos êstes casos aparecem na história da dinastia herodiana, mas correspondem i prática geral, a qual, por sua vez, obedecia às considerações políticas do momento, ou à vontade dos respectivos imperadores (17).

226. - Se o título de socius et amicus populi Romani descrevia, na prática, a posição de todos os reis aliados, parece, contudo, que o título como tal, só ise concedia formalmente a determinados indivíduos. Dêste modo, nem todos aquêles, que haviam obtido esta posição e o correspondente tratamento, tinham formalmente recebido o título de rex socius, ainda que a todos

\footnotetext{
(14). - Herodes obteve a confirmação pelo Serado em 40 (n. 138s), e em 30 a. c. (n. 205), depois de nomeado, a primeira vez, por Marco António e Ọtavianq, a segunda, por Otaviano, o vencedor únioo. Tácito, Historiarúm 5, 9 refcre que, depois da morte de Herodes, um certo Simo ( $=$ Simão) usurpara, na Judéia, o nome de rei, nihil exspectato Caesare, como queria o costume (cf. G. $2,4,2 \S 57 ; 59$. G. 17, 10,6 273-277). Augusto, por muito tempo, mostrou-se indignado com Aretas IV, rei dos nabateus, por êle ter-se feito rei, sem. esperar o s'eu consentimento $(A .16,9,4 \$ 295-297$ e 10,9 \$ 359; ner também $17,9,5 \S 239$.

(15). - Hircano II, de rè que fồra, foi reduzido a simplàs particular por seu irmāo, Aristóbulo III (n. 12), E' reinstalado como sumo-sacerdote e promovido a chefe da nação por Pompeu (n. 14), e a etnarca por César (n. 19), depois que the havia sido cerceado o território por Pompeu (n. 14).

(16). - Entre as exceçōes figura, ao menos de direito, Aderbal da Numídia, o qual diz, em seu discurso perante o Senado, citado por Salústio, Belltum Jugurthintm 14, 1: Jugurtha... contempto imperio vostro Masinissae me nepotem et jam ab stippe socium atque amicum populi Romani regno fortunisque om nibus expulit. - Augusto restituiu a Juba II o reino de seu pai, Júba I. Die Juba II a sucessão passou para seu filho Ptolomeu (Cássio Dión, Historia Romana 51, 15, 6; Estrabão, Geographica 17, 3, 7 [p. 828]). Sôbre a Armênia Maior veja-se Augusto, Res Gestaa, c. 27, 2. Tarcondimoto sucedreu a seu pai no reino da Cilícia (Cássio Dión, ib. 54, 9, 2; Estrabāo, ib. 14, 5, 8 [p. 676] ]. César prochamara amigos e aliados seus a Hircano II a seus descendentes (n. 223).

(17). - Cf. E. Schürer 1, 448s.
} 
êles, perante a lei, se dispensasse tratamento igual (18). Também é sòmente de certos dêstes reis que se afirma, expressamente, terem sido declarados cidadãos romanos, sendo, contudo, provável, que todos o fôssem, coisa que também se afirma de Herodes. Declarado cidadão romano, juntamente com seu pai Antípater, pelo próprio Caio Júlio César (n. 19), teria tido 0 direito de chamar-se Júlio Herodes, assim como o nome de Iúlio podia ser usado por todos os seus descendentes (19). Com Calígula introduziu-se o costume, ao menos temporàriamente, de conceder aos reis aliados honras e atributos senatoriais, pretorianos, e, até, consulares. Agripa I obteve, primeiramente, de Calígula, a dignidade pretoriana, e, em seguida, a consular, de Cláudio (20). Seu irmão, Herodes de Calcis, e seu filho, Agripa II, obtiveram ambos a dignidade pretoriana, o primeiro, de Cláudio, o segundo, de Vespasiano (21).

227. - A soberania dos reis aliados limitava-se nos pontos seguintes: 1 . Não lhes era permitido concluir tratados com outros estados ou povos, nem conduzir guerras por conta própria (22). Sua soberania limitava-se, por conseguinte, às fronteiras do próprio reino, e à política estritamente interior, sendolhes vedado qualquer atividade política exterior pròpriamente dita, e independente. Isto não impedia que os reis aliados se visitassem mùtuamente, ou empreendessem viagens a outras partes do Império (23) . O próprio Herodes desenvolveu enorme atividade no exterior, por meio de grandiosas construções espalhadas pelo Império todo, o que nos autoriza a dedicar um

\footnotetext{
(18). - Receberam o título formalmente, por exemplo, Polemón do Ponto (Cássio Dión, ib. 53, 25, 1), Farnaces do Bósforo (ăb. 37, 14, 2), Ptolomeu VII Evergıte II Fiscon (A. 14, 13, $22 \S 250$ ), Ptolomeu XIII (Sustônio, Caesar 54), Agripa I (A. Reifenberg, Moedas dos 'judeus [trad. hebr.]. Jerusalém 1947,41, n. 63 ).

(19). - E. Schürer 1, 449s e 2, 162, W. Otto 1 e 17; M.-J. Lagrange 180; U. Holzmeister 25. José só fala da cidadania romana de Antípater, A. 14, 8, 3 $\S 137 ; 16,2,4 \S 53 ;$ G. $1,9,5 \S 194$.

(20). - Filón, In Flaccum $6 \S 40$; Cássio Dión, ib. 60, 8, 2.

(21). - Cássio Dión, ib. 3 e 65, 15, 4; cf. E. Schürer 1, 450 e nota 106.

(22). - Herodes moveu guerra aos nabateus por instigação di Cleópatra, e ordens de Marco Antônio (n. 194). A segunda guerra movida contra êles, em 9 a. C., com o consentimento de Sêncio Saturnino, governador da Sítria mas sem o conhecimento de Augusto, custou a Herodes a amizade do imperador ( $A, 16,9,3 \$ 290$ ). Aretas IV moveu guerra contra Herodes Antipas, por ter êste preferido a própria cunhada, Herodiades, a sua filha ( $M c$. 6, 17). As ordens de Tibério foram que Lúcio Vitelio, governador da Siría, the trouxesse o rei árabe, vivo ou morto $(A .18,5,1$ \& 115).

(23). - Arquelau da Capadócia, sôgro de Alexandre, fillho de Herodes e de Mariame, esteve de visita na Judîia (G. 1, 25, 1 \&99-6 \$ 512), assim como também Herodes o visitou em seu reino (A. 16, 4, $6 \& 131$ ). - Inscrições dedicadas a Herodes Antipas nas ilhas de Côs e de Delos, atestam as viagens dêle; cf. E. Schürer 2, $17^{1}$ e E. Gabba, Iscrizioni (vis n. 81) 45s.
} 
parágrafo a sua política exterior. Veremos, ainda, que Augusto era extremamente favorável a que as famílias dos reis aliados se unissem entre si por casamentos (24). - 2. Aos reis aliados só competia o direito de cunhar moedas até certo ponto. Parece que lhes era quase inteiramente interdita a cunhagem de moedas de ouro, e, em muitos casos, também a de moedas de prata, como nos informa a numismática (25). - 3. Em casos de guerra, os reis aliados deviam contribuir com contingentes de tropas auxiliares, e competia-lhes, de modo especial, a defesa das fronteiras do Império (26). Em ocasiões determinadas deviam contribuir, ainda, com dinheiro (n. 229), mas em geral estavam isentos de pagamento de um tributo regular (n. 234). Só de Marco Antônio afirma-se expressamente ter nomeado reis para recolher tributos, entre outros precisamente a Herodes, na Iduméia e na Samaria (27).

228. - Fora destas limitações, e tendo sempre em conta o caráter precário de sua posição em geral (n. 225), gozavam os reis aliados de plena soberania, e de autoridade absolutá, dentro de seus territórios. Competia-lhes a plena administração in-

(24). - Suetônio, Augustus 48. - Um exemplo, contudo, pode mostrar-nos qua1 a verdadeira situação coos reis aliados, e qual o tratamento a que se expunham, apenas ousassem despertar a desconfiança das autoridades romanas. Agripa I reunira em Tiberiades cinco outros reis aliados, seu irmão, Herodes de Calcis, Antíoco da Comagene Sampsigeramo de Emesa, Cotis da Armênia Menor, e Polemón do Ponto. Caio Víbio Marsa, governador da Síria, desconfiado de tanta concórdia, apresenta-se em Tiberíades, e ordena que os diversus reis voltem imediatari?nte para suas respectivas casas $(A .19,8$, $1 \S 338-341$ ).

(25). - Em V. Ehrenberg-A. H. M. Jones, Documents (ver n. 81) mencionam-se várias moedas de prata de reis alíados, uma de Artavasdes III da Armênia e de Augusto (95, n. 181); uma didracma de Artáxies fíta Capadócia e de Germânico (95, n. 182): uma tetradracrza de Cleópatra e de Marco Antônio (96, in. 185). Note-se a emissão conjuntra com os retratos dos chefes romanos. Vejam-se siclos de Tiro em A. Reifenberg, Ancient Hebrew Arts, New York 1950, 88 . Em ambas as revolta judaicas (66-70 e :132 135 d. C.) emitiram-se siclos de prata, ib. 89 e 92. A cidade livre de Ascalão, até meados do século 2 d. C. usava moedas imperiais e autônomạas, las últimas de tamanho mínimo e de menor valor, cf. E. Schürer 3i, 758t.

(26). - Para falar sòmente dos nabateus, vizinhos da Herodes, sabemos que contribuiram tropas auxiliares para a guerra alex.ndrina de ,César, (Bellum Alexandrinum 1: equites ab rege Nabateorum Malcho evocat); para a batalha de Áccio do lado de Marco Antônio (Plutarco, Antonius 61, 2); para a guerra contra Marco Antônio, a convita de Quinto Didio (n. 207); para a carrst panha malograda de Elio Galo contra a Arábia meridional em 25-24 a. C. (Estrabāo, Geographica 16, 4, 22-24 [p. 780-782]); para a campanha de Públio Quintílio Viaro, governador da Síria, contra Jerusalém, depois da morte de Herodes $(A, 1 \%, 10,9 \S 287 ; G, 2,5,1 \S 68$; despachados por excesso de crueldade, devida ao ódio pela memória de Herodes, ib. $3 \S 76$ ); para a campanha de Tito contra Jerusalém (G. $3,4,2 \S 68$; Tácito, Historiarum $5,1)$; cf. E. Schürer 2, 355-359.

(27). - Apiano, De Bello Civiii, 5, 8, 75; E. Schirer 1, 450s. 
terna de seus países; a livre promulgação e execuçằo das leis; o direito ilimitado sôbre a vida e a morte de seus súditos. Dentro dos limites de seus reinos podiam, ainda, impor e recolher impostos e direitos alfandegários a seu bel-prazer, e administrar independentemente suas rendas. Competia-lhes, outrossim, o pleno contrôle sôbre suas tropas, e organizavam-nas como bem lhes parecia (28). Em suma, dentro dos limites de seus respectivos territórios, competia aos reis aliados o pleno poder administrativo, legislativo, executivo e judiciário, e, ainda, lhes competia a plena soberania em matéria de defesa e de finanças.

229. - Se, no tempo que precedeu a instituição do principado de Augusto, as obrigações de um rei, ou de outro príncipe aliado, eram, antes de tudo, o fornecimento de tropas, de mantimentos e de dinheiro, aos respectivos senhores do momento (29), tornaram-se elas posteriormente mais leves. Se lhes incumbia manter a paz com seus vizinhos, cabia-lhes, antes de tudo, mantê-la dentro do próprio país (30). Era esta, aliás, uma das razões, porque era preferível nomear um rei nativo, de preferência a um procurador romano, nas regiões, cujas populações, por um motivo qualquer, eram difíceis de governar. O conhecimento mais íntimo das peculiaridades de seus povos tornavam-nos mais indicados para lidar com êles; seu caráter permanente dava-lhes oportunidade para adquirir maior experiência, do que a que pudesse adquirir um governador, que ficasse em seu posto por um ano apenas, ou mesmo por dois ou três (31); seu caráter nacional devia, na maioria dos casos, facilitar a absorção de seus territórios pelo Império romano, absorção que se iniciava pela própria instituição dêstes prínci-

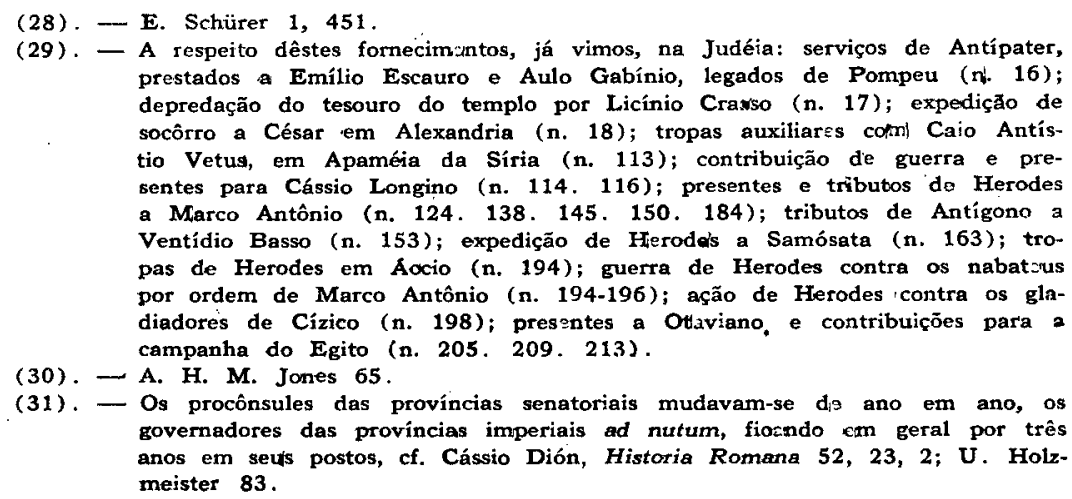
prestados a Emílio Escauro e Aulo Gabínio, legados de Pompeu (n! 16); depredação do tesouro do templo por Licínio Crasso (n. 17); expediçăo de socôrro a César em Alexandria (n. 18); tropas auxiliares cơnl Caio Antístio Vetus, em Apaméia da Síria (n. 113); contribuição de guerra e presentes para Cássio Longino (n. 114. 116); presentes e tributos do Herodes a Marco Antônio (n. 124. 138, 145. 150, 184); tributos de Antígono a Ventídio Basso (n. 153); expedição de Heroda's a Samósata (n. 163); tropas de Herodes em Aocio (n. 194); guerra de Herodes contra os nabatius por ordem de Marco Antônio (n. 194-196); ação de Herodes contra os gladiadores de Cízico (n. 198); presentes a Otaviano, e contribuiçōes para a campanha do Egito (n. 205. 209. 213).

(31). - Os procônsules das províncias senatoriais mudavam-se dis ano em ano, os governadores das provincias imperiais ad nutum, fiozndo em geral por três anos em seús postos, cf. Cássio Dión, Histotia Romana 52, 23, 2; U. Holzmeister 83 
pes aliados. Reinando, em geral, sôbre territórios relativamente limitados, podiam fàcilmente acudir com suas tropas, onde quer que fôsse necessário (32).

230. - Se os reis aliados estavam isentos do pagamento de tributos regulares (n. 234), mantinham, por outro lado, a suas próprias expensas, suas tropas e suas praças fortes, para a segurança interna de seus países, e para a defesa externa do Império. Mantinham, ainda, à sua custa, todo o aparato administrativo de seus territórios, com tôdas as suas dependências. $\mathrm{Da}-$ vam assim fôrça e estabilidade ao Império, sem aumentar-lhe as despesas (33). Em última análise, consistia a função principal dos reis aliados em preparar seus respectivos territórios para a incorporação definitiva ao Império. Seu caráter precário explica-se, precisamente, em vista desta finalidade. Um bom rei aliado habituava seus súditos à ordem e à disciplina romanas; infundia-lhes, na medida do possível, o gôsto pela cultura greco-romana do Império, e treinava-os no exercício do govêrno local. Feito isto, sua missão podia considerar-se terminada, e seu país estava pronto para ser inteiramente absorvido pelo Império, e integrado no sistema do govêrno provincial (34). Desta forma, pois, o bom rei aliado era o melhor instrumento na mão romana para fazer desaparecer os últimos vestígios da independência de seu país. Não admira, diante disto, que muitos dos reis aliados deixassem, desde logo, seus territórios em herança ao povo romano (35).

231. - Dentro das limitações mencionadas, e no pleno gôzo dos restos de soberania que descrevemos, e, ainda, 'em vista da finalidade comum a todos os reis aliados, é que nos devemos imaginar o govêrno de Herodes. Aos olhos dos romanos era êle, certamente, o homem ideal para servir de rei aliado, assim como também os judeus, sempre aos olhos dos romanos, eram o caso típico do povo a ser governado por tal rei. Ciosíssimos de suas liberdades religiosas e suas legítimas aspirações políticas, haviam os judeus causado aos romanos contínuas dificuldades, desde o momento em que Pompeu, em 63 a. C., a pedido, aliás, dos próprios judeus (n. 14), começara a imiscuir-se nos negócios internos da Palestina. As rivalidades entre os dois ra-

\footnotetext{
(32). - Estrabão, Geographica 14, 5, 6 (p. 671) đá o último motivo como razão da anexação da Cilícia Áspera ao reino da Capadócia. Sôbre os diversos pontos tocados no n. 229, ver A. H. M. Jones $65 \mathrm{~s}$.

(33). - F.-M. Abel 1, 361 .

(34). - A. H. M. Jones 66s .

(35). - Fizeram-no Atalo III de Pérgumo (Justino, Epítoma Historiaram Philippicarum 36, 4, 5), Ptolomeu Apín da Cirene (ib. 39, 5, 2), e outros.
} 
mos dos hasmoneus, não só, de tempos em tempos, haviam convulsionado o país (nn. 12-16. 117. 119-121. 129-134), mas ainda haviam dado origem ao banditismo político, entrincheirado sobretudo na Galiléia (nn. 103-106. 159. 161). As susceptibilidades religiosas dos judeus, seu monoteismo rígido e seus costumes multi-seculares, aspectos, todos êstes, incompreensíveis para os gentios de então, dificilmente poderiam ser tidos na devida conta por um governador romano, ou por outro pagão qualquer, apesar dos grandes privilégios que os judeus haviam, pouco a pouco, sabido conquistar.

232. - Herodes, pelo contrário, já havia dado provas sobejas de sua energia férrea na repressão do banditismo, e nela colhera os seus primeiros louros (nn. 103. 159. 161); havia dado provas, igualmente, de seu gênio militar em Samósata (n. 163), na conquista de seu reino (n. 154-168), e na guerra contra os nabateus (n. 195-197). A própria Cleópatra quisera retê-lo como comandante de uma expedição (n. 137), porque sua fama militar devia ter chegado até a ela. A capacidade administrativa, que tão bem serviria a Herodes durante o seu govêrno, já então devia ter-se feito notar, e em sua qualidade de judeu, ao que se supunha, pois era-o ao menos por forma, devia, aos olhos dos romanos, fazer dêle o homem ideal para arcar com as dificuldades provenientes das peculiaridades religiosas dos judeus, quando, de fato, êle se tornaria odioso a seus súditos pagãos, por ser judeu, e a seus súditos judeus, por não o ser (36). Em todo o caso, no exercício de seu cargo de rei aliado, podia Herodes, como todos os seus colegas, contar com o apôio incondicional de Roma, enquanto se submetesse inteiramente às suas ordens, e se mantivesse estritamente dentro dos limites de seu poder. Veremos que êle soube corresponder em tudo às esperanças que em Roma nele se depositavam. Contudo, se êle pudera ufanar-se da amizade pessoal de Marco Antônio (n. 138. 148. 163.184. 189), e mantinha com Augusto e Marco Agripa relações de amizade verdadeiramente cordial (A. $15,10,2 \S 390$ e $3 \S 361 ; 16,9, \S 290$ ), apenas êle ousou, em seus últimos anos, transpor, pela primeira vez, os limites de seu poder, movendo guerra aos árabes, ainda que o fizesse com a autorização do governador da Síria, Augusto lhe mandou dizer que, se o havia tratado, até então, como amigo - фídos - daí em diante tratá-lo-ia como súdito - i ińंкoos - (A. 16, 9, $3 \S 290$ ), e 
assim, pràticamente, o fêz (37). Êste fato descreve òtimamente a situação concreta: Herodes, apesar de amigo, continuava súdito, como todos os reis aliados, a quem Tácito dáí despectivamente, o qualificativo de reges inservientes e instrumenta servitutis (38) .

233. - Nomeado rei, em 40 a. C., tinha Herodes, desde então, o pleno direito ao uso das insígnias reais, costumeiras entre os reis helenísticos da época, isto é, a púrpura, o diadema,
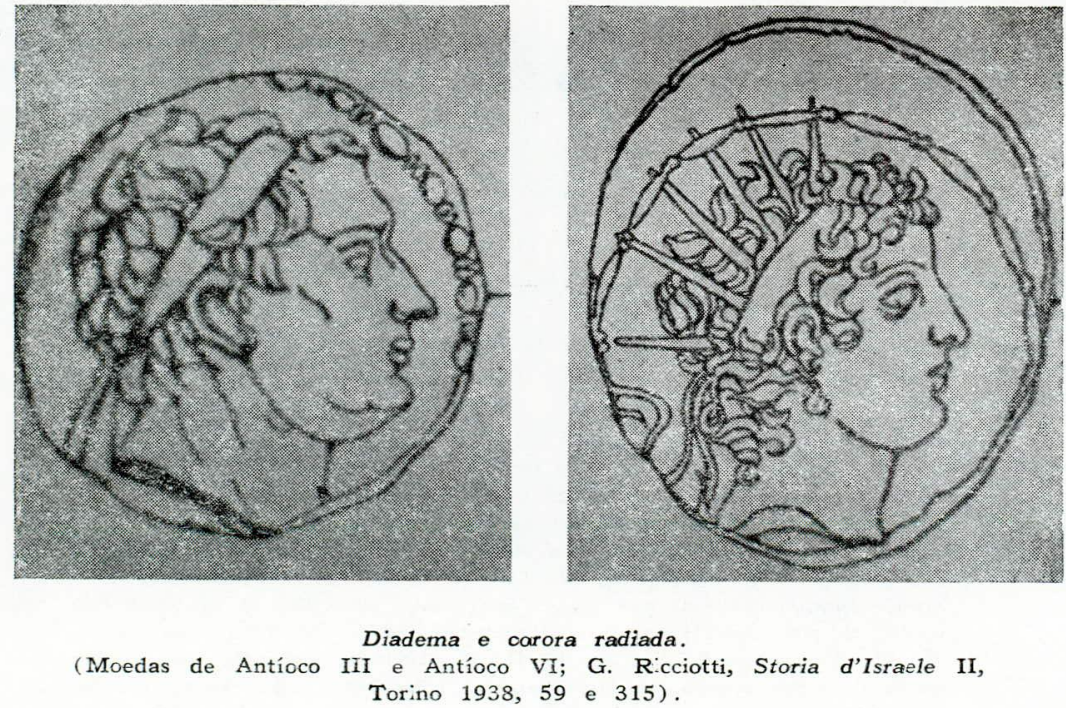

a corôa de ouro, o cetro, e o anel-sinete, podendo, ainda, rodear-

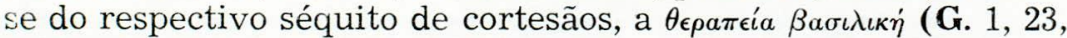
$5 \S 465)$ (39). Bem podiam os romanos deixar aos reis aliados

(37). - Amigo aqui, naturalmente, deve entender-se do amigo pessoal, porque Herodes, ainda quando tratado como súdito, continuava socius et amicus populi Romani. Se assim não fôsse, teria sido deposto.

(38). - Historiarum 2, 81; Aǵricola 14.

(39). - Cf. W. Otto 55. 84 e 107, E. Bikerman 32s. Em 1 Mac. 6, 15 Antíoco IV moribundo entregia sua veste real, sou diadema e seu anel a Filipe, para pas๖á-los adiante a seu filho; cf. 8, 14. Em G. 1, 23, $5 \$ 465$ a veste real é chamada esthês basilikê, em 1, 23, $9 \S 671$ simplesmente porphyra; cf. A. 17, $8,3 \S 197$. Nas duas últimas passagens descreve-se o entêrro de Herodes, e mencionam-se, além da púrpura, o diadema, a corôa de ouro, encimando o diadarra, e o cetro, sustentado na mão direita. O cetro, que se dá como insígnia primitiva das reis em lugar do diadsma (Justino, Epitoma Historiarum Philippirarum $43,3,3)$, não se $m$ nciona entre as insígnias reais dos selêucidas, E. Bikerman $33^{3}$. O anel-sinete fôra confiado, antes da morte do $r \mathrm{i}$, ao chanceler Ptolomeu, para ser entregue a Augusto, juntamente com as con- 
èstes sinais exteriores da pompa helenística, quando sabiam exatamente que êstes mesmos reis dependiam inteiramente dêles, que em sua sobriedade, ainda tingida dos resquícios da simplicidade republicana, miravam apenas ao poder, e não ao aparato exterior, sobretudo numa época em que os próprios reis depurham suas insígnias, para servir, à maneira de clientes, a pes-
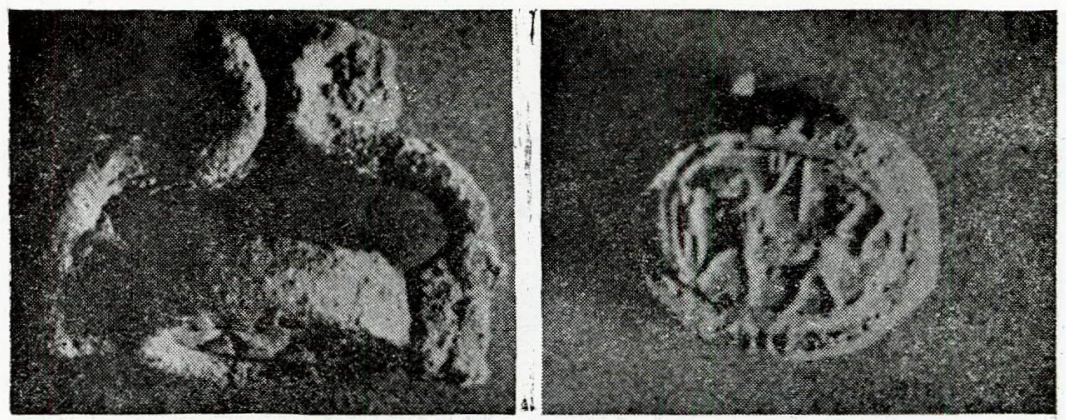

Sigilo de Jotão, rei de Juđá (738-736 a. C.) encontrado em Etsion-guever. (A. Reifenberg, Ancient Hebrew Arts, New York 1950, 33).

tas do reino (G. $1,33,8 \S 667.669 ; 2,2,4 \S 24 ; A .17,8,2 \S 195$ e 9 , $5 \S 228)$. Vejam-se anéis-sinetes hebraicos antigos em A. Reifenberg, Ancient Hebrew Arts, Now York 1950, 33 e 35; sôbre o sinete de Augusto, Suetônio, Augustus 50, o de Pompeu, um leão empunhando uma espada, Plutarco, Pompeius 80,5 ; o dos selêucidas, uma âncora, Apiano, Historia Romana 11, 9, 56; E. Bikerman 33, e, em geral, Ch. Daremberg-E. Saglio. Dictionnaire des anti. quités grecques et romaines I, i, Paris s. a., 293-296. O diadema (de diá e déo = atan ligar), encontra-se representado em bustos e moedas de reis, cf. Ch. Daremberg-E. Saglio, ib. II, i, 119-121. Consistia numa faixa estreita de pano branco, atada ao redor da cabeça, cujas pontas recıiam na nuca. Era a insígnia real mais comum e típica; cingir o diadema era o mesmo que proclamar-se rei (cf. 1 Mac. 1,$10 ; 6,15 ; 8,14 ; 12,39 ; 13,32$ ). O gesto de Herodes, aparecendo sem diadema diante de Otaviano (n. 204), significava, que êle se considerava deposto, em conseqüência da queda de Marco Antônio. A corôa de ouro, que difícilmente poderia representar-se em estátuas, vê-se reproduzida em moedas, em forma de aro estreito, encimado por pontas, à imitação dos raios isolares. Esta corôa radiada, alusìva ao pretenso caráter divino dos monarcas, começa a aparecer nas moedas dos sucessores de Alexandre Magno no século IV a. C. Em Roma dela se serve Nero. Cf. Ch. Daremberg-E. Saglio, ib. I, ii, 1535; L. Cerfaux-J. Tondriau, Le culte des souverains (Bibliothèque de Théologie, Série III. 5), Tournai 1957, 353. 405. E' difícil imaginar a forma da corôa de Herodés. Seus descendentes, ao contrário dêle, não tinham escrúpulos em fazer-se repres ntar em suas moedas. Não aparecem, todavia, coroados, e não nos consta que tenham manifestado aspirações a se tornarem 'objetos de culto (sôbre Act. 12,22 ; A. $19,8,2 \S 345-347$ a seu tempo). Sôbre as diversas formas de cetros ver Ch. Daremberg-E. Saglio, ib. VI, ii, 1115-1119, e sôbre as diversas espécies de púrpura, seu fabrico, seu uso, etc., ib. IV, 1, 769-778, Assumir a púrpura eqüivalia a subir ao trono; cf. 1 Mac. 8, 14; Lactâncio, Divinarum Institutionum 1. 4, 7, 6 (PL 6, 464s): Romains indumentum purpurae insigne est regiae dignitatis assumptae; Eutrópia, Breviarium ab Urbe Condita 
soa de Augusto, revestidos apenas da toga (40). Este contraste entre a pompa helenística e a simplicidade romana, já havia chegado aos ouvidos de Judas Macabeu, quando ouvira dizer, entre outras coisas, que todos aquêles reinam, a quem os romanos prestam auxílio, e querem que reinem, e que êles depõem a quem querem depor, e que haviam atingido uma posição considerável. E, no entanto, nenhum dêles jamais cingira o diadema ou se revestira da púrpura, para engrandecer-se por meio dela (1 Mac. 8, 13s).

234. - Uma certa limitação inicial do poder régio de Herodes parece ter cessado pouco depois de sua confirmação por Otaviano, em 30 a. C. Com efeito, no dizer de Apiano, Marco Antônio havia nomeado rei a Herodes, para recolher os tributos dos samaritanos e dos idumeus. Com outras palavras, entregavam-se-lhe, em 40 a. C., a Samaria e a Iduméia, mediante o pagamento de um tributo (41). Sabemos que Pompeu havia concedido autonomia à cidade da Samaria, e às de Maresa e Adora, ou Adóreos, que dominavam a parte ocidental da Iduméia, enquanto a parte oriental desta, com Hebrón e Masada, continuava sujeita a Hircano II, como se vê pela história anterior de Herodes (42). O tribuno da Iduméia deve referir-se, jor conseguinte, às contribuições dos habitantes da banda ocidental da Iduméia, situada entre Hebrón, de um lado, e os territórios das cidades autônomas do litoral, do outro. No início, portanto, só possuia Herodes, livres de tributos, os territórios judaicos pròpriamente ditos, isto é, a Judéia com a banda oriental da Iduméia, a Galiléia, e a Peréia, ou seja, a Transjordânia, desde a altura do pico de Sartabé (n. 160), até meia altura do

9, 26; Trebélio Polião, Tyranni Triginta 18; Flávio Vopisco. Aureliamus 42, etc. O trono real menciona-se em M. Sanhedrin 2, 5. Herodes Arquelau dá audiência ao povo, sentado num trono de ouro $(G .2,1,1 \S 2$; A. $17,8,4 \S 201$ ), fato que se interpretou como usurpação do poder real, antes da confirmaçāo por Augusto (G. ib. $5 \S 27 ; A$. ib. $9,5 \S 232$ ). Herodes deu um trono de ouro a Arquelau da Capadócia (G. 1, 25, 6 § 511), e nota-se a favor do tetrarca Filipe o fato de ter levado um trono em sulas viagens por suas terras, para poder decidir a qualquer momento as querelas judiciárias de seus súditos $(A .18,4,6 \S 107)$. Ver também Ch. Daremberg-E. Saglio, ib. V, 278-283.

(40). - Suetônio, Augustus 60: Reges amici atque socii... saepe regnis relictis, non Romiae modo sed et provincias peragranti quotidiana officia togati ac sine regio insigni, more clientium praestiterunt.

(41). - De Bello Civili 5, 8, 75; cf. n. 141 e 150.

(42). - Cf. F.-M. Abel, Géographie 2, 147. Sôbre Maresa = tell sandahanna (n. 134. 152), Adora $=$ dura, a Adoraim de 2 Par. 11, 9, etc, a 8 quiliómetros a sudoeste de Hebrón, ib. 379 e 239; A. 14, 4, 4 \&5; G. 1, 7, 7 $\$ 156$. Herodes em sua fuga para Masada encontra-se em Oresa, perto de Hebrón, com seu irmão José (n. 133). 
mar Morto, limitada, ao norte, e a leste, pelos territórios das cidades autônomas da Decápole, e, ao sul, pelo país dos nabateus, o qual incluia, naquele tempo, a cidade de Bersabé (43). Desta forma a posição de Herodes, de início, não se avantajava muito sôbre a de Hircano II (44). Dez anos mais tarde, contudo, em 30 a. C., recebeu Herodes de Augusto a Samaria, o que só pode referir-se à remissão do tributo mencionado (n. 211). Não lemos o mesmo a respeito da Iduméia ocidental, mas pode presumir-se que idêntica remissão se aplicasse também a ela, e, por conseguinte, que todo o reino de Herodes, daí por diante, ficasse isento de tributo (45). O mesmo vale dizer, sem dúvida, dos territórios posteriormente acrescentados ao país

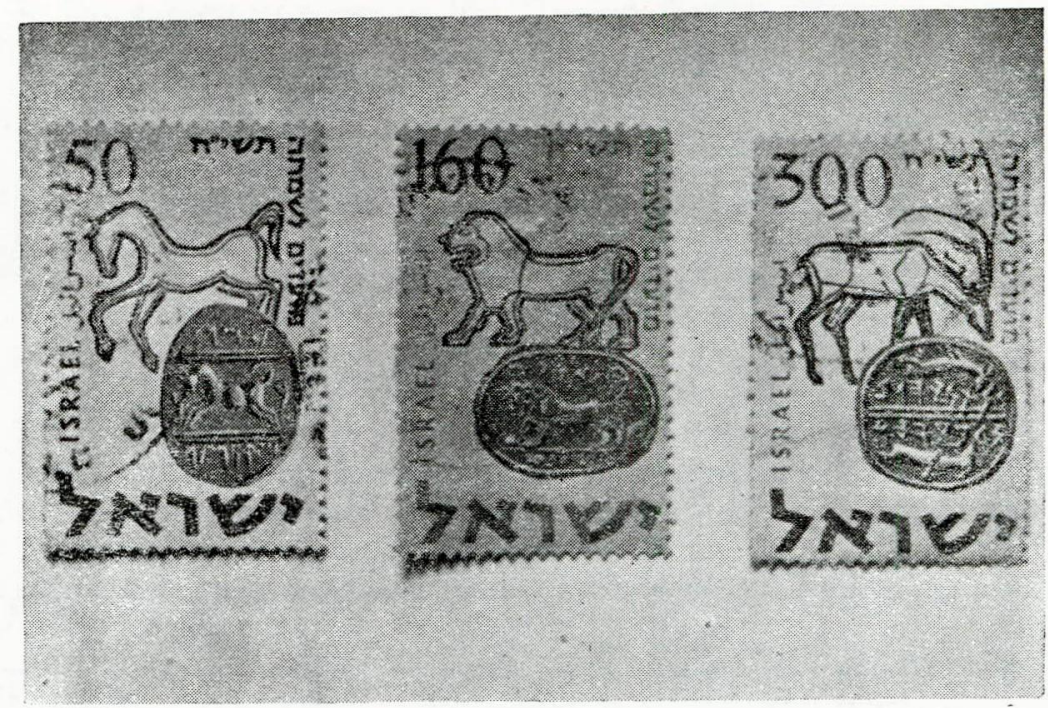

Sigilos hebraicos antigos reproduzidos em selos do atual Estado de Israe1.

(43). - F.-M. Abel, Géographie 2, 147.

(44). - W. Otto 55 .

(45). - W. Otto 55, F.-M. Abe1 1, 361\%; M.-J. Lagrange 177. Diferem J. Felten 1 , 148; A. H. M. Jones $64 \mathrm{~s}$, o qual diz: Whether Herod continued to pay a regular tribute is uncertain, but a fixed sum had been stipulated in his original appointment as $\mathrm{king}$, and it seems on the whole unlikely that Augustus would have forgone this perfectlyl legitimate claim. - O proprio Herodes, em seu discurso às tropas, durante a primeira guerra contra os nabateus (nota 63 do capítulo precedente), diz que não convinha que os judeus pagassem tributo a quem quer que fôsse ( $A .15,5,3 \S 133$ ). Refere-se ao pagamento das rendas por Jericó, estipuladas com Cleópatra (n. 190). Isto supõe que o resto do território judaico, à exaeção da Samaria e da Iduméia, não estivesse sujeito ao pagamento de um tributo regular. 
por Augusto (46). Vimos, contudo, que a isenção de tributos era amplamente compensada pelos reis aliados em geral, pela manutenção de tropas e de praças fortes, e pela organização e a manutenção do aparato administrativo de seus respectivos países (n. 230), e já notamos igualmente que Herodes em particular, excedia-se em. espalhar, pelo Império todo, provas de sua munificência e de sua devoção para com Roma'(n. 220).

235. - A Judéia estava, além disto, isenta de ocupação por parte de tropas romanas, privilégio que já havia sido garantido por César a Hircano II, em 47 a. C. (n. 19), e que constituia uma das grandes prerrogativas dos estados aliados (47). Não se prova o contrário pela presença de uma legião romana perto de Jerusalém em $34 / 5$.C. (A. 15, $3,7 \S 194$ ), que se explica perfeitamente pelo desêjo de Herodes, de subjugar definitivamente seu reino com o auxílio de tropas romanas, e mantê-lo cm paz durante sua visita a Marco Antônio em Laodicéia da Síria (n. 184. 188). Terá despedido 'seus protetores, tẫo logo lhe fôra possível (48). Também os distúrbios que se deram na Judéia depois da morte de Herodes, mostram que, naquela ocasião, ali não se encontravam tropas romanas, que só então $9 \S 286-11,1 \S 303)$. Arquelau com efeito ,enviara um quiliarca à frente de uma coorte ao templo, a fim de reprimir um motim do povo. Esta coorte foi quase inteiramente exterminada a pedradas pelo povo enfurecido (G. $2,1,3 \S 11 ;$ A. $17,9,8 \S 215$ s). O fato, porém, de nada ouvirmos a respeito de eventuais represálias por parte dos romanos, é prova suficiente para dizer, que não se tratava, no caso, de tropas romanas, mas que José, como de costume, emprega em sentido largo os eqüivalentes gregos dos têrmos técni.cos militares romanos (49). Pode supor-se, por conseguinte, que Herodes, como os outros reis aliados, gozava de plena soberania no govêrno militar de seu reino. Este aspecto, contudo, de sua soberania, bem como os de seu poder legislativo, executivo e judiciário, suas finanças e sua administração, deverão ocupar-nos ao examinarmos seu govêrno sob todos os seus aspectos.

236. - Um privilégio seu, que nenhum outro rei aliado jamais obtivera de Augusto, era um amplo direito de extradição, que o tornava, no dizer de José, temível não só para seus ami-

(46). - M.-J. Lagrange 177 .

(47). - W. Otto 56 .

(48). - W. Otto 42 e 56; M.-J. Lagrange 177.

(49). ‥ W. Otto 56; cf. U. Holzmeister 33 . 
gos dentro de seu reino, mas também para os de além de seus limites (G. 1, 24, $2 \S 474$ ). Podia, em vista dêste privilégio, exigir a entrega de um súdito fugitivo, de qualquer $\pi \boldsymbol{\alpha}_{\lambda \iota s}$, cidade ou estado, fora de sua jurisdição. Talvez se deva êste privilégio, como pensam alguns, à posição da Judéia nas vizinhanças idos territórios árabes, infestados por nômades e bandidos, e especialmente indicados, em vista de seu caráter montanhoso e áspero, para servir de refúgio a tôda a sorte de fugitivos perante a lei ou a cólera de Herodes. :Deve notar-se, contudo, que a afirmação de José é peremptória, e que êle refere êste privilégio de Herodes na ocasião, em que trata de suas desavenças com seus filhos Alexandre e Aristóbulo, filhos de Mariame, dos quais nem os mais íntimos do rei podiam aproximar-se. A menção do privilégio de extradição, nesta altura, só pode significar que aos dois jovens não restava sequer o expediente da fuga para outro país, súdito ou aliado aos romanos, incluindo a Capadócia, reino do sôgro de Alexandre, porque mesmo lá, por privilégio especial de Augusto, alcança-los-ia a ira implacável e o braço do pai. Se podemos supor que a informação de José se baseia em Nicolau de Damasco, devemos conceder que êste devia estar ao par dos costumes da época (50). Herodes apelou, em vão, para êste seu direito de extradição, por ocasião de distúrbios que se deram na Traconítide, quando quarenta bandidos se refugiaram com os nabateus, onde foram bem recebidos. Herodes, autorizado por Sêncio Saturnino, governador da Síria, exigiu repetidas vêzes a entrega dos malfeitores, e chegouse a combinar, diante dos chefes romanos da Síria, a entrega mútua dos refugiados políticos. Como os árabes não cumprissem o estipulado, foi Herodes autorizado pelos mesmos chefes romanos a intervir pela fôrça, o que the custou a amizade de Augusto (A. 16, 9, 1-3 e 10,8). Por onde podemos concluir que o privilégio de extradição não incluia sua aplicação pela fôrÇá (51).

237. - Outro privilégio de Herodes, de que não temos exemplo na história dos outros reis aliados, foi o direito, expressa-

\footnotetext{
(50). - W. Otto 62 pensa na tradição favorável a Herodes. Contudo, nenhum autor consultado, nem os editôres das obras anotadas de José, injługnam o privilégio em apreço, nem ainda cittam exemplos, que demonstrem que o mesmo não tenha sido único. Ver também $J$. Juster, Les juifs dans l'empire romain II, Paris 1914,145 e nota 2 .

(51). - As informaçōes do José devem, contudo, ser completadas pela menção de uma espécie de tratado de extradição a favor dos próprios judeus, em 139 a. C., sob o govêrno de Simão Maqabreu ( 1 Mac. 15, 21); cf. J. Juster, ib. $145^{\circ}$. Todavia, naquela época só podia tratar-se de uma recomendação, por parte de Roma, a seus aliadols (enumerados em 1 Mac. 15, 22s).
} 
mente concedido por Augusto, em 22 a. C., de designar livremente seu sucessor, direito que implicava, evidentemente, a aceitação dêste, de antemão, por parte de Roma. Com efeito, quando Herodes, naquele ano, levou seus filhos, Alexandre e Aristóbulo, filhos de Mariame, a Roma, e os apresentou a Augusto, êste os recebeu com o maior carinho, e concedeu a Herodes dar o seu reino a um de seus filhos, a quem êle designasse -

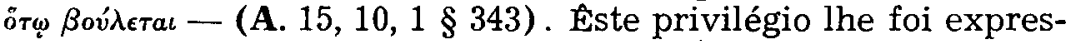
samente confirmado em 12 a. C., quando ise apresentou com os mesmos filhos diante de Augusto, em Aqüiléia, para acusá-los. A defesa de Alexandre a tal ponto comoveu os presentes, que se procedeu a uma reconciliação imediata e geral, sob a condição de que os filhos prestassem ao pai obediência incondicional. e ficando estipulado que êle pudesse deixar o reino a quem qui-

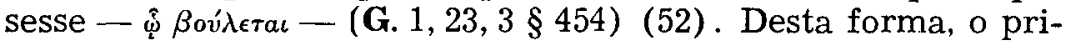
vilégio era, ao mesmo tempo, uma arma nas mãos do pai, para reduzir seus filhos à obediência para com êle, e à concórdia entre si (G. $1,23,5 \S 457.459)$.

238. - De fato, porém, já no mesmo ano de 12 a. C., Herodes nomeou a seus três filhos, Antípater, filho de Doris (n. 122), Alexandre e Aristóbulo, filhos de Mariame, sucessores seus, como reis (G. $1,23,5 \S 458 ;$ A. $16,4,6 \S 133$ (53), fazendo, uso, por conseguinte, do privilégio alternativo, igualmente concedido por Augusto, de poder deixar o seu reino, por partes, a vários de seus filhos (A. 16, 4, $5 \S 129$ ). Significavam êstes privilégios que Roma prorrogava para além da morte de Herodes o contrato unilateral de vassalagem, que a ela o unia, e lhe concedia a perspectiva de poder fundar uma dinastia hereditária (54). Roma abria mão de seu direito, de examinar sòmente depois da morte do soberano, a quem se concedera a soberania ad personam, se esta autonomia relativa devia perpetuar-se na pessoa de seus herdeiros, ou se o país deveria passar para a administração direta de funcionários romanos. Contudo, se Roma dava um privilégio ao pai, e concedia uma oportunidade aos filhos, sempre ela se reservava o direito de rever estas nomeações, e, em caso de necessidade, de anulá-las, como aconteceu, de fato, com dois dos herdeiros efetivos de Herodes, Arquelau e An-

\footnotetext{
(52). - Cf. ib. $5 \S 458$ : Êle (Augusto) me deixou senhor do reino, e árb tro da nomeação de um sucessor - dikastên diadóchou -; $A .16,4,1 \S 92$ e $5 \$ 129$.

(53). - Conforme G. 1, 23, $2 \S 451$ já antes da viagem a Aqüiléia nomeara a Antípater sucessor seu.

(54). - W. Otto $62 \mathrm{~s}$.
} 
tipas, ambos depostos por Roma, o primeiro, por incompetência, o segundo, em conseqüência da ambição de Herodias, sua mulher.

239. - Herodes perdeu, contudo, nos últimos anos de sua vida, o privilégio singular de poder nomear, independentemente, seu sucessor, ou sucessores. Em seu último testamento fazia depender suas disposições da aprovação de Augusto (G. 1, 23, $\varepsilon \S 669 ; \mathbf{A} .17,8,2 \S 195)$. Arquelau, em conseqüência disto, recusava-se, com tôda a razão, a aceitar o título de rei, enquanto o testamento de seu pai não fôsse confirmado pelo imperador (G. 2, $1,1 \S 2$ s; A. $17,8,4 \S 202$ ). Ainda no ano anterior, em 5 a. C., Antípater havia sido enviado a Roma com outro testamento de seu pai (G. 1, 29, 2 §573; A. 17, 3, 2 §53). A demora na aprovação, ainda que parcial, do último testamento, prova que em Roma já se estava pensando de outro modo, e se contava com a possibilidade de uma eventual supressão do estado judaico, de acôrdo, aliás, com os desejos expressos da nação (G. 2, 6, 1 § 80-2 §91; A. 17, 11, 1-2) . O mesmo prova a chegada, logo depois da morte de Herodes, de Sabino, procurador da província da Síria, com a intenção de tomar posse das fortalezas e dos bens do rei (G. 2, $2,2 \S 16-18$ e $3,1 \S 41$; A. $17,9,4 \S 228$ ). Ainda neste sentido poderá interpretar-se a entrega, em Roma, do relatório das finanças públicas do rei, na mesma ocasião (G. $2,2,4 \S 24$; A. 17, 9, 4 § 228). Êstes fatos só se explicam satisfatòriamente, se admitirmos, que, depois de 12 a. C., ano em que Herodes nomeara três de seus filhos sucessores seus, como se viu, foi-lhe tirado o privilégio de poder nomear livremente seu sucessor, ou seus sucessores (55).

240. - Nossas fontes não mencionam, diretamente, a supressão dêste privilégio, mas deixam entrevê-la suficientemente. E', contudo, difícil, definir-lhe o motivo exato, e parece antes tratar-se de uma combinação de diversos motivos, entre os quais devia figurar, naturalmente, a guerra de Herodes, empreendida em $10 / 9$ a. C. contra os árabes, por conta própria, e que provocou a já mencionada indignação de Augusto, com a ameaça de já não mais o tratar como um amigo, mas como um súdito (n. 232). Devem juntar-se a isto as terríveis discórdias entre o rei e seus filhos, não desconhecidas de Augusto, o qual já se empenhara em desfazê-las (56). Note-se que Herodes, em 7/6 a. C., mandara executar, com a autorização de Augus-

\footnotetext{
(55). - W. Otto 63; M.-J. Lagränge 180; U. Holzmeister 35, enquanto R. H. Pfeiffer 33 pensa que Herodes agiu por deferência para com Augusto.

(56). - Cf. W. Otto 127 , e o n. 237 .
} 
to, a Alexandre e Aristóbulo, isto é, dois dos filhos, já por êle mesmo, em 12 a. C., designados sucessores seus (n. 238). Em todo o caso, a partir desta época, ou, mais exatamente, a partir do incidente da guerra com os árabes, já não encontramos sinal algum de favor especial, ou de amizade, da parte de Augusto. Êstes diversos motivos coincidem ainda com certa tendência, que se pode observar em Roma, precisamente nos últimos anos de Herodes, em desenvolver sempre mais o princípio da idéia monárquica, tendência que se manifesta, por exemplo, na exigência do juramento de fidelidade ao imperador, a ser prestado por todos os cidadãos do Império (57) .

241. - Excetuando, pois, os privilégios mencionados, concedidos à sua pessoa, estava Herodes sujeito às limitações que cerceavam a soberania de todos os reis aliados. Como rei aliado, vassalo de Roma, não lhe competia, por conseguinte, nenhuma iniciativa independente em matéria de política exterior, seja dentro ou seja fora dos limites do Império. Não lhe competia concluir tratados, nem fazer guerras por conta própria: Já mencionamos, várias vêzes, que a invasão do território dos nabateus, em 10/9 a. C., ainda que com o consentimento do legado da Síria, provocou extrema indignação de Augusto, e turvou definitivamente as boas relações entre êste e Herodes (n. 232. 240). Este último, contudo, ainda dentro dêstes limites, soube, a seu modo, desenvolver uma política exterior ativíssima, e inteiramente conforme aos desejos de Roma. De fato, outro nome não merece a tremenda atividade construtora, por êle desenvolvida nos mais variados pontos do Império, de que vimos um primeiro exemplo, em 40 a. C., ainda nos primórdios de sua carreira política, em sua contribuição para a reconstrução de Rodes (n. 147). No mesmo sentido devem interpretar-se as visitas a outros estados e soberanos; as visitas de estrangeiros honorificamente por êle recebidos; os presentes régios, distribuídos às mancheias; os auxílios materiais, fornecidos às províncias flageladas por sêcas e epidemias; os casamentos, promovidos entre membros de sua família, e os de soberanos estrangeiros, política inteiramente conforme aos desejos de Augusto (58); o interêsse demonstrado ativamente pela revivescência dos jogos olímpicos, e, até, sua irtervenção a favor dos judeus da Diáspora. Como dissemos,

(57). - Cf. W. Otto 127, e os nn. $245 \mathrm{~s}$.

(58). - Suetônio, Aứcustus 48: Reges socios etiam inter sametipsos necessitudinibus mutuis junxit, promptissimus affinitatis cujusque atque amicitiae conciliator et fautor. 
êstes fatos todos nos autorizam a dedicarmos um parágrafo especial à política exterior de Herodes, ao tratarmos dos diversos aspectos de seu govêrno.

242. - Até ao presente só se encontraram moedas de ,bronze de Herodes. Conclui-se daí que não lhe era lícito cunhar moedas de ouro ou de prata (59). Êste fato daria a entender que êle, privilegiado como era sob certos aspectos, não o era sob outros, e não pertencia em tôdas as coisas à classe mais privilegiada dos reis aliados, como parecem sugerir certas passagens de José (60). Convém notar, por outro lado, que os hasmoneus, ainda no tempo de sua plena independência, se limitavam a cunhar moedas de bronze (61). Com efeito, a emissão de moedas dêste tipo mais modesto bastava para assinalar a soberania nacional, enquanto as moedas mais valiosas dos estados helenísticos, e as de Roma, posteriormente, serviam para o comércio internacional, e para assegurar o lastro de ouro necessário à estabilidade do tesouro nacional. Outros pormenores estudar-se-ão no parágrafo sôbre as finanças de Herodes.

243. - Também o poder judiciário indiscriminado de Herodes sofreu certas limitações em seus últimos anos. Vimos que no início de seu reinado êle procedia livremente contra os memkros de sua família, entregando à 'morte sua mulher Mariame, seu tio José, seus cunhados Aristóbulo III e Costobar, além de muitos outros. Contudo, já em 12 a. C., apresenta-se, com seus filhos Alexandre e Aristóbulo diante de Augusto, e o primeiro lhe diz, em sua defesa diante do imperador: Era-te lícito, tanto em virtude de tua autoridade régia, quanto em virtude de tua autoridade de pai, executar os culpados (A. 16, 4, $3 \S 106$; G. $1,23,3 \S 452$ ). Estas palavras, juntamente com o fato de se celebrar o processo em presença de Augusto, parece sugerir, não já que Herodes assim procedia por escrúpulo, mas que lhe havia sido ti1 ado o direito de proceder, como rei, e como pai, contra seus filhos, em causas capitais. Não se trata, todavia, de uma diminuição de seu poder judiciário como tal, mas de uma medida de ordém política, ou, então, de direito internacional. Tratava-se, com efeito, de herdeiros eventuais ao trono de $\mathrm{He}$ -

\footnotetext{
(59). W. Schürer 1, 450; W. Otto 61; U. Holzmeister 34 (conforme F. W. Madden 105-114, e G. F. Hilf 220-227, citados ambos no n. 83); A. R. S. Kennedy (n. 83) 426s; A. Reifenberg, Moedas dos judeus (trad, hebr.), Jerusalérn, 1947, $17 \mathrm{~s}$.

(60). - E. Schürer 1, 450 .

(61). - W. Otto 61 .
} 
rodes (62). Agravou-se, naturalmente, aquela restrição depois do ano de 12 a. C., após ter Herodes efetivamente nomeado sucessores seus a Antípater, Alexandre e Aristóbulo (n. 238). Tendo obtido o privilégio de nomear livremente seus sucessores, êstes, uma vez nomeados, podiam dizer-se ipso facto reconhecidos por Roma, assim como já usavam de certos atributos da realeza (63). Vemos, em conseqüência disto, que o segundo processo movido contra Alexandre e Aristóbulo, por ordem de Augusto, se celebra em Beirute, transformada em colônia romana, diante de um tribunal misto judaico-romano, e que a execução da sentença capital é diferida até chegar a autorização expressa do imperador. Do mesmo modo esperou-se, mais tarde, a decisão dêste, para executar a pena capital no caso de Antípater, o que se deu ainda cinco dias antes da morte do rei

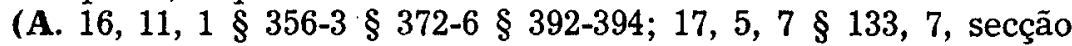
única § 182-187; G. $1,27,1 \S 536-3 \S 543$. $6 \S 550$ s. $32,5 \S 640$. $33,7 \S 661-664)$.

244. - Como todos os reis aliados, assim também Herodes devia concorrer, e, efetivamente, concorreu, com tropas auxiliares em caso, ou, então, em perigo de guerra!(n. 227), como já o fizera em tempos de Marco Antônio (n. 194-196). Com efeito, em 25/4 a. C., enviou quinhentos soldados de sua guarda pessoal, cavalarianos, com tôda a certeza, para servir a Élio Galo, prefeito do Egito, em sua malograda campanha contra a Arábia meridional (A. 15, 9, 3 § 317). Nela igualmente participaram tropas de Malcos, rei dos nabateus, e é a seu ministro Sileu, que Estrabão atribui o malôgro da expedição (64). A contribuição de Herodes devia ser tanto mais valiosa aos olhos dos romanos, quanto a Judéia por aquêles anos estava sendo desolada por sêcas, peste e fome, devendo Herodes recorrer a Petrônio, sucessor de Élio Galo, para aliviar as necessidades de seu povo, e as da província da Síria (A. 15, 9, 1-2). Mais tarde, em 14 a. C., na iminência de uma guerra no Ponto, Herodes foi juntar-se com sua frota a Marco Agripa. José quer fazernos crer que esta visita tenha sido espontânea e inesperada, 'e que Herodes tivesse combatido ao lado de Agripa (A. 16, 2, 2, $\S 21-23)$. Contudo, a passagem em questão ressente-se da historiografia oficial de Nicolau de Damasco. Sabemos, com efei-

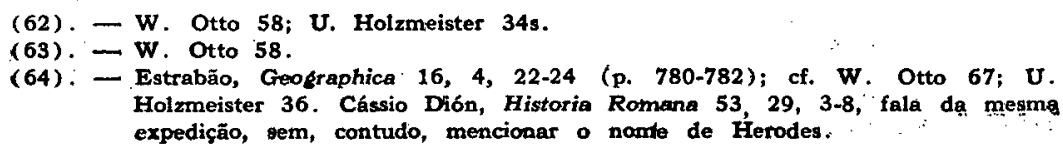


to, por outras fontes, que a chegada de Marco Agripa no mar Negro foi suficiente para fazer com que os distúrbios cessassem por si. A presença de Herodes nada mais terá sido, que o cumprimento de seus deveres de rei aliado, e a chamado do próprio Agripa (65). Se o rei não teve outra ocasião para demonstrar seu zêlo pela causa de Roma, em ocasiões semelhantes, devia-o ao influxo benéfico da paz romana, inaugurac'a por Augusto (n. 209).

245. - E' certo que, ao menos nos últimos anos de Herodes, seus súditos foram obrigados a prestar um juramento de fidelidade ao imperador, tornando-se êles, desta forma, súditos diretos de dois soberanos, não só porque já o eram de Herodes por vontade de Roma, mas porque o rei teve a habilidade de incluir neste mesmo juramento a fidelidade aos interêsses de sua própria pessoa. Os habitantes da Judéia deviam com efeito, jurar a 'ểvoca para com Augusto, e para com os negócios do

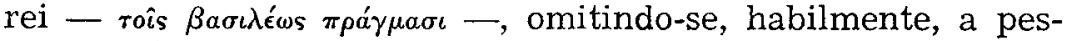
soa do rei como tal, e mencionando-se a fidelidade para com os seus interêsses em segundo lugar (A. 17, 2, 4 § 42) (66). Esta exigência, contudo, não provinha de uma modificação qualquer na situação interna da Judéia, exigindo tal medida de segurança, mas explica-se pelo crescente desenvolvimento da idéia monárquica em Roma, e relaciona-se com o juramento que, a partir de c. de 15 a. C., se exigia em tôdas as províncias do Império, relacionado, por sua vez, com o censo dos cidadãos, e o breviarium totius imperii (67). José parece ser o primeiro autor, que fala do juramento de fidelidade a ser prestado pelos simples cidadãos, sendo o segundo testemunho, ao que parece, o juramento dos paflagônios, de 3 a. C. (68).

246. - O juramento foi, de fato, prestado pela grande maioria da população da Judéia, que dêste modo começava a assimilar-se aos habitantes das províncias do Império (69).

\footnotetext{
(65). - W. Otto 72; cf. Cássio Dión, ib. 54, 24, 6s.

(66). - W. Otto 61 e 95.

(67). - Suetônio, Augurstus 101; Tácito, Annalium 1, 11; cf. Augusto, Res Gestae, c. 8, 2 e 25, 2; U. Holzmeister 35 e 39.

(68). - E. Schürer 1, 44594; V. Ehrenberg-A. H. M. Jones (ver n. 81) 136, n. 315 . Comparando A. 17, 2, $4 \$ 42$ cam 15, 10, $4 \& 368$ discute-se, ise ambas as passagens se referem a um só juramento, ou se a sigunda trata de um juramento /anterior, prestado em c. de 20 a. C. E. Schürer, ib.; A. H. M. Jones 74; J. Juster, Les jutifs dans l'empire romain $I_{;}$Paris 1914, 344, etc., admitem dois juramentos; W. Otto $62 \mathrm{~s}$ (texto e nota) um só. U. Holzmeister 35 não se pronuncia.

(69). - W. Otto 62 .
} 
E' provável que o juramento se repetisse por ocasião do advento de Tibério, porque sabemos que os judeus da Palestina juraram fidelidade a Calígula (A. 18, 5, 3 § 124), e consta por outros testemunhos que houve províncias em que os cidadãos juraram fidelidade ao primeiro (70). Os judeus da Diáspora, a exemplo do patriarca José, que jurou pela vida de faraó (Gen. 42 , 15), não viam dificuldade alguma em jurar fidelidade ao imperador, ou em jurar por seu nome, mas é de se supor que as penalidades impostas aos recalcitrantes fôssem mais severas do que as impostas aos judeus da Palestina, com os quais a legislação romaria, na medida do possivel, sempre usou de consideração. Podemos supor, por conseguinte, que a fórmula do juramento, imposta aos judeus palestinenses, fôsse tal, que não repugnava a seus sentimentos religiosos, pois dificilmente êles jurariam, por exemplo, pela fortuna de César, ou por fórmulas semelhantes, que contivessem algum ressaibo de idolatria. Como nos informa José, o essencial da fórmula con-

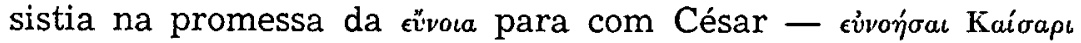
(A. 17, 2, 4 § 42) -, precisamente como no mencionado juramento dos palagônios (71). De fato, sòmente seis mil fariseus se recusaram a prestar o juramento, e os essênios dêle foram simplesmente dispensados (A. 15, 10, $4 \S 368-371 ; 17,2$, $4 \S 42$ ).

247. - Uma certa limitação do poder de Herodes, que se deu durante êste mesmo período do maior esplendor do seu govêrno, pode, talvez, ver-se na nomeação, em 20 a. C., por ocasião da visita de Augusto à Síria, de Feroras, seu irmão mais novo, e, agora, único, para tetrarca da Peréia (n. 234). José nos diz, que êle mesmo pediu esta tetrarquia para o irmão, ajuntando-lhe ainda êle mesmo a subvenção de cem talentos, para torná-lo independente dos favores de seus próprios filhos, depois de sua morte. Feroras teria, ainda, participado em tudo das honras da realeza, excetuado o diadema (A. $15,10,3 \S 362 ; 16,7,3 \S 193 ;$ G. $1,24,5 \S 483$ ). E' certo, sem dúvida, que isto não se deve entender de uma participa-

\footnotetext{
(70). - Tácito, Annalium 1, 7 e 34. Sôbre o juramento prestado a Calígula, temos inscriçōes de Aritium, na Lusitânia, e de Assos, na Tróada (E. Schürer 1, 44504); sôbre o prestado a Trajano, temos de Plínio, o Moço, Epistolae, 1. 10, Epistola 60 (ad Traianum) e Epistola 103 (Traiani ad Plinium).

(71). - V. Ehrenberg-A. H. M. Jones (ver n. 81) 136, n. 315; J. Juster ib. $344^{\circ}$. Em A. 13, 3, 4 \& 76 os judeus, diante de Ptolomeu VI Filometor, juram por Deus e pelo rei. Num piaptro do Fayum, de 101 ,d. C. (BGU, n. 1068), citado por J. Juster, ib. $344^{\circ}$, o judeu Soteles, filho de José, jura por Trajano. Contudo, nos Atos siríacos de S. Silvestre os judeus juram pelo diadema do imperidor, ib. $344^{\circ}$.
} 
ção positiva de Feroras no govêrno da Judéia (72). Tornavase êle tetrarca-vassalo de seu irmão, como êste e Fasael, o irmão mais velho de ambos, o haviam sido de Hircano II, quando por Marco Antônio haviam sido nomeados tetrarcas da Galiléia e da Judéia respectivamente (n. 126). Do mesmo modo o próprio Herodes, em seu último testamento, nomearia a Arquelau seu herdeiro principal, a Antipas tetrarca da Galiléia e da Peréia, e a Filipe tetrarca das regiões a leste da Galiléia (G. $1,33,7 \S 664$ combinado com 8 § 668; A. 17, 8, 1 § 188s). Devia, portanto, perpetuar-se entre seus filhos a relação de dependência que existia entre êle e seu irmão Feroras (73). Augusto, contudo, achou mais conveniente abolir o reino da Judéia como tal, e confirmar os três sucessores de Herodes como príncipes independentes entre si (G. 2, 6, $3 \S 93 \mathrm{~s} ;$ A. $17,11,4 \S 318 \mathrm{~s}$ ).

248. - Diante do que conhecemos do caráter de Herodes, há quem não queira conceder, que êle tenha cedido, voluntàriamente, ainda que fôsse a um irmão seu, uma parte sequer de seu reino. Devemos notar, além disto, que diversas doações de Augusto haviam aumentado consideràvelmente os territórios de Herodes, e, precisamente nesta mesma ocasião êle recebia mais um acréscimo territorial. Podia, pois, parecer conveniente aos olhos de Roma, contrabalançar o poder e os recursos financeiros de Herodes pela nomeação de um tetrarcavassalo, uma vez que as rendas da nova tetrarquia passariam às mãos do tetrarca. Desta forma, não seria impossivel que a nomeação de Feroras partisse diretamente de Roma, e que Herodes apenas conseguisse que a nova tetrarquia se concedesse a seu irmão, de preferência a um outro qualquer (74). A fonte de José hàbilmente teria disfarçado em sinal de benevolência, o que nada mais era do que uma medida política de Roma. Explicar-se-ia igualmente a reserva prudente que Herodes mostrava para com Feroras nas subseqüentes intrigas domésticas, reserva devida mais a um representante de Roma, do que a um irmão (75). Seria de notar, ainda, a ironia do destino, pois, assim como Marco Antônio, comprado por Herodes, o impusera a êle e a seu irmão Fasael como tetrarcas a Hircano II (n. 126. 145), cerceando assim os poderes dêste, assim, agora, se impunha a Herodes um tetrarca-vassalo, ainda

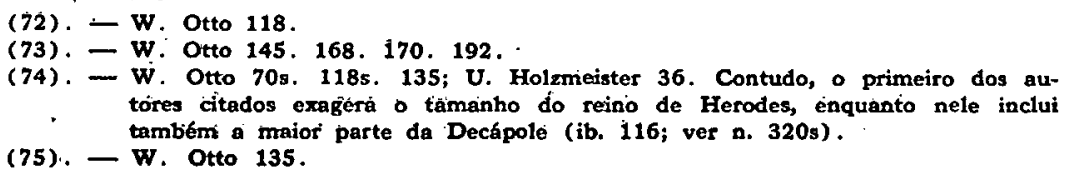


que fôsse a pessoa de seu irmão (76). Teria sido possível, outrossim, que Roma visava ainda o fortalecimento da fronteira, pela presença de mais um chefe militar e político nas vizinhanças imediatas dos nabateus, sempre irrequietos e inclinados a se mostrarem independentes (77). Neste ponto, contudo, Roma deveria ver-se lograda em suas intenções, uma vez que Feroras preferiu continuar intrigando na côrte do irmão, a passar longe de Jerusalém, em sua tetrarquia nada convidativa, para onde só se retirou, quando rompeu definitivamente com o irmão, e por ordem dêste (A. 17, 3, 3 § 58-60; G. $1,29,4 \S 578-581)$.

249. - Contudo, devemos tomar em consideração o forte sentimento de família de que era possuído Herodes (n. 99), e do qual já vimos diversas provas, como, por exemplo, na vingança pelo assassinato de seu pai (n. 115s), e no ódio com o qual perseguiu os responsáveis, diretos ou indiretos, pela morte de seus irmãos Fasael e José (nn. '134. 136. 165), pois não podemos deixar de ver na execução ignominiosa de Antígono, além dos motivos de ordem política (n. 170. 176), uma vingança pela morte de ambos os irmãos, e pelo ultraje praticado no cadáver de José (n. 164). Nesta sêde de vingança pode ver-se, talvez, um vestígio do sangue árabe de Herodes, herdado através de sua mãe (n. 88). José, com efeito, nos refere expressamente, que os árabes tinham uma lei, que os obrigava a vingar, por todos os modos, a morte dos seus (A. 16, 9, 1 \& 277). Qualquer que tenha sido a ação de Hircano II na nomeação de Herodes e de Fasael para tetrarcas (n. 126), fôra Herodes quem comprara a Marco Antônio, e a nomeação de ambos só se deve a manobras suas (n. 126. 145). No entanto, era precisamente Fasael, o mais velho dos irmãos, e presente no centro da Judéia, quem tinha as maiores oportunidades para apoderar-se do govêrno da nação. Se a morte de Fasael significava a remoção de um eventual concorrente de Herodes (n. 143), não há dúvida, por outro lado, que êste o amava sinceramente, ainda quando não saibamos qual teria sido a atitude que êle teria tomado no combate final pelo trono. Não se exclui, todavia, que os irmãos já tivessem chegado a um acôrdo sôbre quem deveria tomar a liderança final, e que Herodes apenas ficasse

(76). - W. Otto 71. 119.

(77). - Vejam-se, por exemplo, sua negligência no pagamento das rendas devidias a Cleópatra e a Herodiss, causa da primeira guerra (n. 194-196), e suas intrigas por ocasiāo dos distúrbios na Traconítide, o que provocou a segunda guerra (n. 236). Já notamos, que Aretas IV não esperou o consentimr.nto de Augusto para proclamar-se rei (nota 14 đêste capitulo). 
com sua província original, por ser esta a mais difícil de controlar (n. 102). Notemos, ainda, o importante papel que $\mathbf{S a -}$ lomé desempenhará na vida de seu irmão Herodes, sobretudo nos últimos anos da vida dêste. $E^{\prime}$ difícil julgar, se êle jamais. chegou a compreender até que ponto se extendia a influência sinistra dela, ou se o seu sentimento de família o impedia de percebê-lo. Em todo o caso, deixou-lhe um importante legado em seu testamento (G. $1,32,7 \S 346 ; 2,6,3 \S 98 ;$ A. $17,11,5$ $\S 321$ ).

250. - Ora, é preciso fazer valer os mesmos sentimentos de Herodes a favor de seu irmão mais novo, Feroras. Este já se encontrava entre os membros de sua família, que êle pusera em lugar seguro, na fortaleza de Masada, por ocasião de sua fuga de Jerusalém, e de sua primeira viagem a Roma, em 40 a. C. (n. 133). Pouco depois vemô-lo participar lealmente ra campanha pela conquista do reino. Enquanto José participava ativamente na guerra, na qual deixaria a vida (n. 159. 164), Feroras esteve ocupado na retaguarda, tratando do aprovisionamento das tropas romanas de Silo, e da reconstrução da fortaleza de Alexandreion (n. 160). Em vista dos sentimentos de família de Herodes, é compreensivel que tratasse com especial carinho a seu irmão caçula, tendo perdido na guerra, no espaço de poucos anos, seus irmãos Fasael e José. Não se exclui, por conseguinte, que tenha pedido e obtido para êle, cêrca de vinte anos mais tarde, o pôsto e as honras de tetrarcavassalo. Com isto nada cedia de seu poder, porque seu próprio ascendente bastava para lhe garantir a supremacia em tudo, como demonstrariam os fatos posteriores. Vê-se por êstes mesmos fatos que Feroras nunca passara do estágio de rapaz mal educado e cabeçudo, e, quiçá, o cargo de tetrarca devia servir-lhe de ocasião para mostrar algum senso de responsabilidade. Naturalmente, uma vez nomeado por Roma, Herodes devia a êle o respeito e a consideração que convinham a um representante dela, além de tratá-lo com a habitual indulgência fraternal. Também a pensão de cem talentos, concedida a seu irmão, sugere que as honras pedidas para êle, partiam, de fato, de um coração sincero. Diante de tudo isto é preferivel seguir os autores em geral, que aceitam, sem mais, a versão de José (78). 
251. - Dada a posição de Herodes como rei aliado de Roma, não será sem interêsse examinar os trâmites, dentro dos quais se processavam suas relações oficiais com Roma. Todos os negócios do Império vinham parar, naturalmente, nas secretarias imperiais, ou seja, nas mãos dos libertos de Augusto. E' do tempo dêste, com efeito, que data a ascendência crescente dos libertos nos negócios do estado, que levaria aos abusos que puderam observar-se nos tempos de Cláudio (79). Diante disto, é interessante notar, que Herodes, em seu testamento, além de deixar mil talentos a Augusto, deixou ainda quinhentos a Livia, e aos libertos e amigos do imperador (G. $1,32,7 \S 646 ; \mathbf{A} \cdot 17,6,1 \S 146$ e $8,1 \S 190)$. Este fato é tanto mais notável, quanto Herodes, em sua primeira estada em Roma, em 40 a. C., por ocasião de sua nomeação para rei, aí só passou sete dias (n. 142), e isto numa época, em que o ascendente de Augusto apenas se fazia sentir, e nada deixava prever que um dia êle e os seus haveriam de governar o mundo. Contudo, foi suficiente aquela semana, para Herodes travar amizade com um dos cônsules daquêle ano, Caio Asínio Polião (n. 140), um dos homens mais notáveis da época. Lemos, com efeito, que dezessete anos mais tarde, em 23 a. C., quando Herodes enviou três de seus filhos, para se educarem em Roma, êles se hospedaram em casa daquele ilustre político e homem de letras, a quem José chama amicíssimo de Herodes (A. 15, 10, 1 \& 343; cf. (i. 1, 22, 2 § 435). Não podemos negar que o novo rei, naquela semana memorável, teve ocasião para adquirir outros amigos ainda, mais ou menos desinteressados, uma vez que, sempre de novo, ouvimos falar em dinheiro, ao se tratar da pessoa de Herodes, e de suas relações com Roma (nn. 110. 124. 138. 145. 147. 168. 176. 184, 205. 209).

252. - Sabemos, efetivamente, que êle contava com amigos em Roma, que se interessavam por seus negócios junto de Augusto, e o mantinham ao par dos acontecimentos. Além disto, é lícito supor, que êle mantinha um ou mais agentes na capital do Império, uma espécie de embaixadores permanentes, ou encarregados de negócios (80), como o faria seu filho Arquelau (A. 17, 13, $2 \S 343$ ). Assim, por exemplo, Augusto, quando lhe foi referida a invasão, em 10/9 a. C., do território nabateu, pediu informações aos representantes de Herodes, que se achavam presentes - "H pứdov oi mapóvres —, além de interrogar

\footnotetext{
(79.). - L. Friedländer, Sittengeschichte Roms, Wien 1934, 37-56; A. Piccarolo, Augusto o seu século, São Paula, 1939, 57.

(80). - W. Otto 125; A. H. M. Jones 63 .
} 
seus próprios informantes, vindos da Síria (A. 16, 9, $3 \S 289$ ). Aqui, com efeito, não parece haver dúvida, de que se trata de agentes diplomáticos herodianos, acreditados na côrte imperial. Pouco depois ouvimos que o rei tentava aproximar-se do imperador, indignado com êle, por meio de seus amigos - $\delta i \grave{a} \tau \hat{\omega} \hat{\nu} \phi i ́ \lambda \omega v$ -, para esclarecer o acontecido. Nicolau de Damasco incumbiuse desta missão delicada (A. 16, 9, 4 § 299). Ouvimos, ainda, que Antípater, o primogênito de Herodes, na esperança de adiantar seus planos de sucessão, tentou captar as simpatias dos amigos de

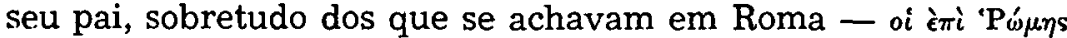
$\phi i \lambda o \iota-($ A. $17,1,1 \S 6)$. Conseguiu, realmente, que êles se interessassem pela contenda (A. 17, 4, $3 \S 80$ s). Depois do processo contra seus filhos, em Beirute, Herodes procura saber por Nicolau, apenas tornado de Roma, qual a opinião de seus amigos romanos a respeito do caso (A. 16, 11, $3 \S 370$ ). Não lhe era difícil adquirir tais amigos, nem lhe faltavam ocasiões para isso. Suas relações oficiais com o govêrno provincial da Síria punham-no em contacto com um sem número de funcionários romanos (n. 255), e, assim como seu filho Antípater tentou comprar o apôio de Saturmino, governador daquela província; e a de seu irmão (A. 17, 1, 1 § 6s), da mesma forma Herodes, conforme aprendera por longa prática, desde os tempos de Marco Antônio (n. 251), terá feito uso dos meios à sua disposição, maiores, sem dúvida, que os de seu filho.

253. - Suas visitas oficiosas a'Augusto, na Síria, em 20 a. C., e a Marco Agripa, na Ásia, em 22/1, em 15, e em 14 a. C., bem como suas diversas viagens a Roma, foram outras tantas ccasióes para alargar o círculo de seus amigos romanos. Era, sobretudo, a amizade de Marco Agripa, que lhe devia ser útil em Roma, quando lá se encontrasse durante os intervalos entre suas diversas missões na Ásia (n. 264). Também seus filhos, que se educavam na capital, deviam contribuir automàticamente, para manter viva a lembrança do pai, e sabemos, que conseguiram, realmente, fazer amigos entre os libertos de Augusto (A. $17,12,2 \S 332$; cf. G. $2,7,2 \S 106-109)$. Não pouco terão feito, neste sentido, os preceptores de ambos, Andrômaco e Gemelo, velhos amigos do pai (A. 16, 8, 3-4) (81). Sabemos, ainda, positivamente, que outro filho do rei, Herodes Antipas, igualmente edu-

(81). - Própriamente falando, é só de Gemelo, que se afirma, expressamente, sua presença em Roma, junto de Alexandre $(A, 16,8,3 \S 242 s)$. Seu nome, além disto, sugere, que tonha sido romeno, $W$. Otto 87 . Contudo, também de Andrómaco, de origem grega, ao que pirece, afinirya-so ter sido preceptor dos filhos de Herodes (ib.), o 6 provável, que ambos tenham continuado $\mathrm{cm}$ Roma, junto dos dois principes. 
cado em Roma, juntamente com seu irmão Filipe, conseguiu estabelecer sólida amizade com Tibério, futuro sucessor de Augusto (A. 18, 2, $3 \S 36$; cf. 5, 1, § 114s; G. 2, 9, 5 § 178). E' preciso ter presente, outrossim, que o retor Teodoro, preceptor de Tibério, era natural de Gádara, e, por conseguinte, desde 30 a. C., súdito, mais ou menos direto, de Herodes (n. 211). Não se exclui, todavia, que tenha compartilhado as antipatias de seus compatriotas contra o regime de Herodes, das quais ainda teremos que ocupar-nos (n. 268). Parece que entre os próprios judeus de Roma houvesse simpatizantes de Herodes, uma vez que encontramos na capital do Império, entre as treze sinagogas, cuja existência se comprova pela arqueologia, uma sinagoga de herodianos - 'H $\rho \omega \delta \dot{\delta} \omega \nu$ - (82). Contudo, não podemos definir, até que ponto se extendia a influência, direta ou indireta, dos judeus romanos na côrte de Augusto, e é certo que a maioria dêles era anti-herodiana, como prova sua atuação, junto de Augusto, depois da morte do rei (G. $2,6,1 \S 80 ; \mathbf{A} .17,11,1 \S 300)$.

254. - E' certo, por outro lado, como veremos a 'seu'tempo, que, na terminologia da época, фí̀o designa muitas vêzes uma categoria mais graduada de funcionários régios. E' muito possível, por conseguinte, que no número dos amigos romanos de Herodes se incluissem seus agentes diplomáticos permanentes, e os preceptores e servidores de seus filhos, sem que se deva dizer, contudo, que em todos os casos mencionados os amigos romanos signifiquem apenas os funcionários herodianos, residentes em Roma. Com efeito, quando José nos diz que Antípater procurava captar, por meio de, somas ingentes, as simpatias dos amigos romanos de seu pai, ajunta logo, que entre êstes se encontravam Saturnino, governador da Síria, e seu irmão (A. 17, $1,1 \S 6 \mathrm{~s})$. Ora, é pouco provável, que ambos se mencionassem, sem mais, com os amigos romanos de Herodes, se êstes apenas designassem funcionários seus. Contudo, a presença dêles na côrto de Augusto é tanto mais natural, quanto era de interêsse vital para os negócios do rei, que estivesse ao par dos acontecimentos, e a êles adaptasse sua conduta, quando sua posição de rei aliado, dependendo em tudo da boa vontade de Augusto, aconselhava a demonstração contínua de sua eficiência e de sua utilidade como tal. Do mesmo modo podemos imaginar-nos a presença de agentes herodianos na Âsia, junto de Marco Agripa,

\footnotetext{
(82). - G. Ricciotti 224; J. Felten 1, 2891; J. Juster, ib. 4148; J.-B, Frey, Le Judaisme à Rome aux premiers temps de l'E glise, Biblica 12 (1931) 131; id., Corpus Inscriptionum Judaicarum I, Città del Vaticano 1936, LXXII e 124126, n. 173.
} 
quando das duas regências dêste no Oriente romano (n. 264), e, ainda assim, junto do govêrno provincial da Síria.

255. - Com efeito, não sòmente fôra Herodes nomeado por Augusto conselheiro das finanças daquela província (n. 268), mas parece, ainda, que as autoridades desta estavam autorizadas a resolver, conjuntamente com êle, determinados assuntos relativos aos negócios da Judéia. Ambos os fatos são, evidentemente, provas da confiança que Roma nele depositava, e era sobretudo a última concessão, aliás, inteiramente justificada pela vizinhança dos territórios respectivos, e em vista dos interêsses comuns na defesa das fronteiras do Império, que evitava a Herodes as despesas, e, sobretudo, as demoras das comunicações diretas com Roma (83), seja por terra, seja por mar, não obstante o sistema de comunicações òtimamente organizado, daquela época (84). Vemos, por conseguinte, que Herodes se entende diretamente com as autoridades da Síria, quando de suas dificuldades com os habitantes da Traconítide e os nabateus (n. 232). Seu filho Antípater lhe segue o exemplo, quando procura comprar a adesão de Saturnino e de seu irmão (n. 252). Herodes tem todo o interêsse em socorrer a província da Síria, durante a sêca de $25 / 4$ a. C. (n. 244). Saturnino é consultado a respeito de alguns conjurados, antes que fôssem enviados a Roma, para lá serem julgados (G. 1, 29, 3 § 577). Por outro lado, receberam os chefes romanos da província instruções expressas de Augusto, ou, então, foram convidados por Herodes, para assistir aos diversos processos instaurados contra os seus filhos. Saturnino com seus três filhos, Volúmnio, e outros romanos, assistem ao processo contra Alexandre e Aristóbulo, celebrado em Beirute (A. 16, 11, 3 § 368s; G. $1,27,2 \S 538$ e $3 \S 541$ s), e o legado Quintílio Varo assiste, em Jerusalém, ao processo contra Antípater (A. 17, 5, 2-7) . O mencionado Volúmnio parece ter tido outras ocasiões de entrar em contacto com os negócios da Judéia, adquirindo desta forma as simpatias do povo, pois encontramos em Roma mencionada uma sinagoga de Volúmnio (A. 16, 9, 1 § $277.10,8 \S 344$ e $11,3 \S$ 369) (85).

256. - Parece mesmo que as autoridades romanas da Síria representassem oficialmente os interêsses de Augusto tam-

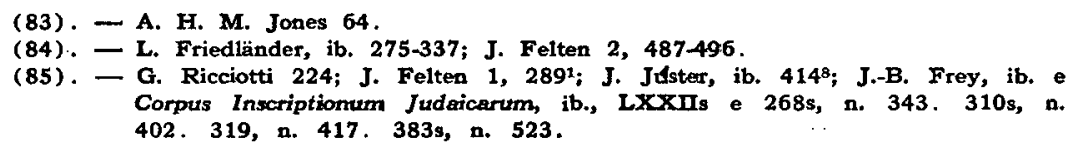


bém na Judéia. Com efeito, nada ouvimos de um representante permanente do imperador na côrte de Jerusalém. ao contrário do que acontecia na côrte mais longínqüa dos nabateus, onde um escravo imperial, da confiança de Augusto, representava as seus interêsses (86). E' só em tempos de Cláudio que ouvimos falar de um certo Estêvão, escravo imperial, assaltado e roubado por bandidos judaicos (G. $2,12,2 \S 228 ;$ A. $20,5,4 \S$ 113), sem que se diga a razão de sua presença na Judéia, já então regida por procuradores romanos. Poucas, pelo contrário, foram as relações oficiais de Herodes com as autoridades romanas de outra província, vizinha da Judéia, o Egito, que confinava com aquela pelos territórios de Gaza e de Rafia (n. 192). Só sabemos que um contingente judaico tomou parte na expedição malograda de Élio Galo, prefeito do Egito, contra a Arábia meridional, em $25 / 24$ a. C. (n. 244), e que Herodes adquiriu de Petrônio, sucessor de Élio Galo, grandes quantidades de trigo, por ocasião da fome, que flagelou a Síria e a Palestina por aquêle mesmo tempo (n. 244). E' provável, contudo, que as autoridades romanas do Egito, bem como as da Síria, estivessem de ouvidos atentos para os negócios da Judéia, como Herodes devia ter seus informantes e agentes em ambas as províncias, hem como em outros pontos vitais do Império, como era natural.

257: - Os negócios mais importantes do reino eram confiados a embaixadas especiais, ou, então, o próprio rei se incumbia de levá-los, pessoalmente, ao conhecimento de Augusto. Assim, fora de suas visitas de cortesia a Augusto, em 20 a. C., na Síria, e, em 18/17 a. C., em Roma, e as visitas a Marco Agripa, regente da parte oriental do Império, temos a viagem para junto de Augusto em Aqüiléia, em 12 a. C., para levar ao conhecimento do imperador a causa instaurada contra Alexandre e Aristóbulo (n. 237) . Contudo, pouco tempo depois, quando se tratava de aplacar as iras de Augusto, incorridas por motivo da invasão do território árabe, em 10/9 a. C., é incumbido Nicolau de Damasco desta missão de confiança, secundado, em seguida, por Olimpo e Volúmnio, outros dois servidores da confiança do rei (A. 16, 9, 4 § 299 e 10, 7-9). O mesmo Nicolau já fôra incumbido da defesa, diante de Marco Agripa, dos interêsses dos judeus da Ásia (n. 269). Olimpo e Volúmnio alcançaram

(86). - A. H. M. Jones 62s. Em G. 1, 29, 3 \& 575s aparece Fabuto, administrador de Augusto, nas intrigas entre Ferodes e Sileu, ministro do rei dos nabateus. Em A. 17, 3, $2 \S 54$ o mesmo é chamado escravo de Augusto, e Sileu é acusado de o ter assassinado. Bste último fato só podia dar-se, se Fabato residia em Petra. 
ainda que Augusto autorizasse o novo processo contra Alexandre e Aristóbulo (A. 16, 10, 9-11, 1), e outros enviados, ainda, conseguiram que o mesmo Augusto tomasse certas providências no caso de Antípater, e autorizasse a execução do mesmo (G. $1,32,7 \S 546$ e $33,7 \S 661$; A. $17,5,7$ s. 6,1 \& 146 e 7,1 \$ 182). O resto dos negócios do reino ter-se-á efetuado diretamente pelos correios imperiais, e a maior parte dos mesmos terão sido despachados pelos secretários de Augusto, quando não requeriam sua atenção imediata (87).

258. - II. Herodes, vassalo de Augusto. - Côncio de sua absoluta dependência de Roma, procurava Herodes, por todos os meios, continuar nas boas graças dela, como já o fizera nos tempos de Marco Antônio, e dos chefes romanos anteriores. Esta ânsia exprimia-se, de uma parte, pelo cumprimento exato de seus deveres como rei aliado, de outra, por demonstrações espontâneas de sua boa vontade em servir o Império (n. 221). Já mencionamos as ocasiões em que enviou contingentes de tropas para juntar-se às fôrças romanas, sendo que na segunda êle mesmo se pôs à testa de sua frota, para conduzí-la para junto de seu amigo Marco Agripa (n. 244). Em seguida, ao estudarmos os diversos aspectos de seu govêrno, veremos como êle se desempenhou das outras obrigações e incumbêncicas de um rei aliado (n. 229s). Contudo, além destas relações, que podemos chamar de oficiais, com Roma, existiam os laços que o prendiam à pessoa de Augusto, no qual, afinal, se encarnavam a idéia e a autoridade de Roma, e do qual 'Herodes diretamente dependia (n. 225). Estudaremos, a seguir, êste aspecto mais pessoal das relações entre Augusto, e seu rei-vassalo, a quem, segundo suas próprias palavras, sempre tratara como amigo, até poucos anos antes de sua morte (n. 232).

259. - Demonstrações da devoção de Herodes para com seu augusto fautor, temos, em primeiro lugar, nos nomes que se deu a si, e que impôs às cidades e aos edifícios, que construia, ou reconstruia (88). Sabemos, por exemplo, por duas inscrições, encontradas em Atenas, que êle adotara os epítetos de

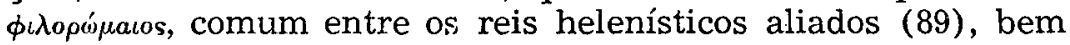

\footnotetext{
(87). - Carta de Augusto a Herodes citam-se em A. 16, 9, $3 \S 290$ e 11, 1 § 356. Em $16,9,3 \S 289$ também se fala de mensagairo vindos da Síria.

(88). - Ver G. 1, 21, 1 \$ 40): Não sòmente dava os nomes de seus patronos (Augusto e Agripa) a edifícios, mas extendeu sua munaficếndia a cidades inteiras.

(89). - Ver inscriçṓes de Așandrọ, Dinamis è Aspurgo do Bósforo, e de Dejótaro de Galácia, em V. Ebreņberg-A. H. M. Jones (ver n. 81) 94, n. 170-172, e 174 .
} 


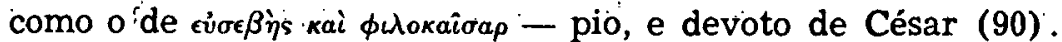
A diferença entre êstes epítetos fêz com que se pensasse em dois Herodes diversos, sendo o segundo seu neto, Herodes de Calcis (91). Sabe-se, contudo, pela numismática, que êste usava o

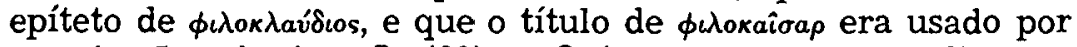
seu irmão, Agripa I (92). Outros procuram explicar a diversidade, datando as inscrições de duas épocas diver-

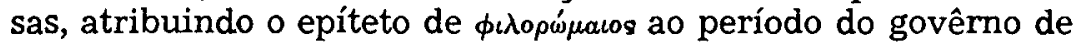

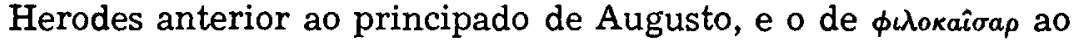
período posterior (93). Deve notar-se, todavia, que se trata de inscrições mandadas executar, não pelo próprio Herodes, mas por outros, os quais podiam não estar ao par dos epítetos que aquêle usava (94). Além disto, sabemos pela epigrafia que certos reis aliados usavam ambas as expressões ao mesmo tempo, entre êstes precisamente os dois descendentes de Herodes, Agripa I, e Agripa II (95) .

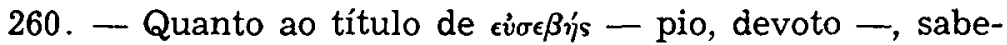

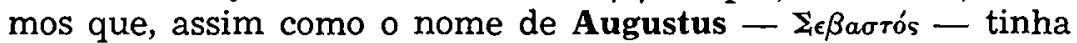
um sabor sacro, e mesmo divino (96), assim o de $\epsilon \dot{v} \sigma \epsilon \beta \eta^{\prime} s$ podia referir-se, de modo especial, ao culto do imperador, do qual He-

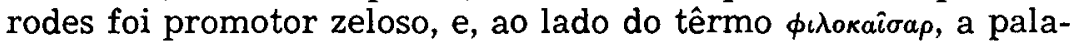

(90). - Corpus Inscriptionum Graecarum (ver n. 81) II, i, n. 551 e 550 . Ver ambas as inscriçöes em $E$. Schürer $2,343^{54}$; a primeira em V. Ehrenberg-A. H. M. Jones (ver n. 81) 95, n. 178, e em E. Nadhmanson, Historische Attische Inschriften (Kleine Texte 110), 2 ed., Berlin 1931; 62, n. 68; U. Holzmeister 47.

(91). - E. Schürer 2, 3435s.

(92). - E. Schürer, ib.; W. Otto 74s. Cf. A. Reifenberg, Moedas das judeus (trad. hebr.), Jerusalem 1947, 42, nn. 68 e 69 , e $41, \mathrm{nn} .60 .60 \mathrm{a} .61 .62$ e 63 . Ver também A. Deissmann, Licht vom Osten, 4, ed., Tübingen 1923, 324.

(93). - W. Otto 75; M.-J. Lagrange 1771; F.-M. Abel 3624.

(94). - M.-J. Lagrange 177 pensa que se trata de títulos oficiais, recebidos sucessivamente. Outros, com mais nazão, supōem que se trata de epítetos, que Herodes se atribuia a si mesmo, $W$. Otto 75 e 107; U. Hoytemeister 36 .

(95). - Ver E. Gabbay Iscrizioni greche latine per lo studio della Bibblia (Sintesi dell'Oriente e della Bibbia 3), Torino 1958, 100, n. 39 inscrição encontrada em Seeia = Sía, na Batanéia. Ambos, os reis, além do título de eusebês, levam os de philokaisar e de philorômarios. Portanto, se Agripa $\mathbf{Y}$, em suas mbodas, só usavia do título de philokaisar (nota 480), isto não impedia que êle mesmo, è outros; The acrescentassem o de philorômaios. Ver, ainda, inscriçāo de Asándroco do Bósforo, em V. Ehrenberg-A. H. :M. Jones (ver $n$. 81) 94, n. 172, a outras inscriçōes em J.-B. Froy, Corpus Inscriptionum Judaricarutu I, Città del Vaticano 1936,495 , n. 683.569, n. 65*. 577, n. 78*.

(96). - J. Juster, Les juifs dans l'emptro ramain 1, Paris 1914; 3431: sacré, adorable; L. Cerfaux-J. Tondriau, Lo cille des sousverains dans la civilisation eréco-romaine (Bibliothèque de Théologie, Sérte III, 5), Tournai 1957, 330s; ef. Augusto, Res Gestad, c. 34, 2; Cássio Díbn, Historia Romana 53, 16, 8; Suetônio, Ausurstics 7; Ovídio, Fasti 1, 589, etc. 
vra dificilmente poderá referir-se a outra coisa (97). Em suas moedas, contudo, Herodes geralmente se contenta com a simples

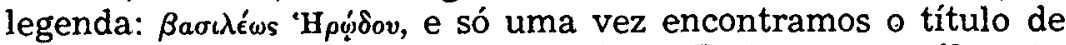

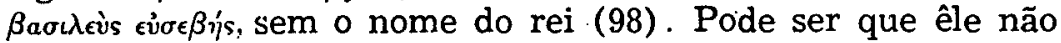
quis afastar-se do modêlo das moedas dos hasmoneus (99), ou, então, evitava o título de rei dos judeus, que, aos olhos dos contemporâneos, mal informados, ou, então, mal indispostos para com os judeus, evocava um povo reacionário, por ser avêsso à cultura helenística (n. 71): De resto, Herodes 'era, na época, o único rei dêste nome.

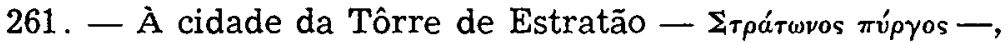
concedida a Herodes por Augusto, em 30 a. C: (n. 211), e sun-

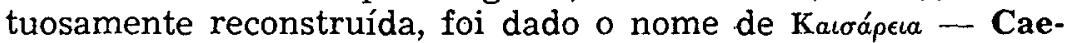
saraea Maritima, ou Palaestinae (100), a.seu pôrto o nome de

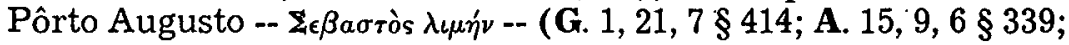
$17,5,1 \S 87$ ) (101). Nesta mesma cidade deu-se o nome de $\Delta$ povoos cu $\Delta$ ovófıov a uma das tôrres, em honra de Nero Cláudio Druso, filho de Lívia, e enteado de Augusto (G. 1, 21, $6 \S 412 ;$ A. 15, 9, $6 \S 336)$. À cidade de Samaria, igualmente dada por Augusto (n. 211), e inteiramente reconstruída por Herodes, foi dado o nome de $\Sigma_{\epsilon} \beta a \sigma r \eta$, que ainda hoje conserva (= Sebastiye; G. 1, 21, $2 \S 403$; cf. $1,5,4 \S 118 ; 1,31,3 \S 613 ;$ A. $15,8,5 \S 292)$ (102). Aos dois edifícios principais de seu novo palácio de Jerusalém deu o rei os

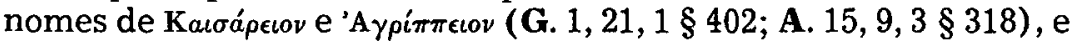

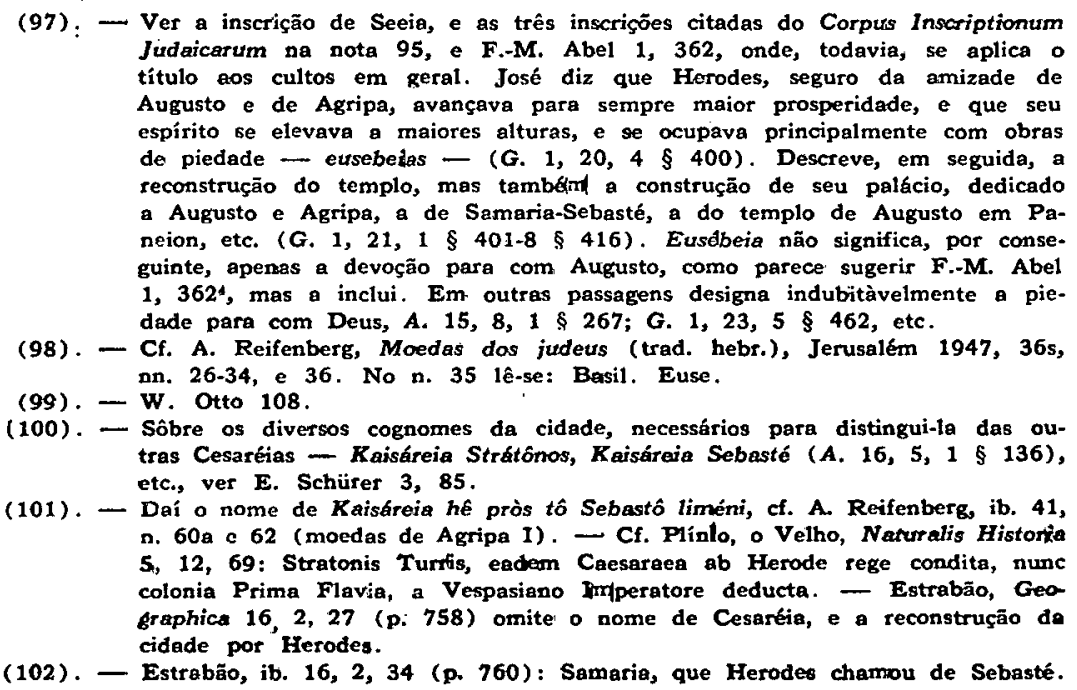


○ mesmo fêz 'com as novas construções erigidas em Jericó (G. $1,21,4 \S 407)$. O nome de 'A $\gamma \rho i \pi \pi \epsilon \iota v$ ou 'A $\gamma \rho i \pi \pi \imath a s$ foi igualmente dado, em honra de Marco Agripa, genro e mais íntimo colaborador de Augusto, à cidade de Antedón, vizinha de Gaza, que igualmente fôra dada por Augusto (n. 211), e reconstruída por Herodes (G. $1,21,8 \S 416$; cf. $1,4,2 \S 87$ e $5,4 \S 118$; A. $13,3,3$ $\S 357$ ), e o nome do mesmo Agripa fôra gravado numa das portas do templo (G. 1, 21, 8 § 416) (103). Enfim, como diz José, é impossível indicar um lugar dentro de seu reino, que Herodes deixasse sem sinal algum de sua devoção para com Augusto, e depois de encher o próprio país com templos, fêz com que as memórias de sua devoção se extravazassem na província, e em muitas cidades levantou templos a Augusto (G. 1, 21, $4 \S$ 407). (104). Note-se que a mania de Herodes de dar os nomes de Augusto e de Agripa aos edifícios e às cidades por êle construídas, ou reconstruídas, coincide precisamente com o período de sua atividade construtora, enquanto no primeiro período de seu reinado só temos o nome de Marco Antônio idado à tôrre Antônia, a $\beta \bar{a} \rho$ ts dos macabeus (n. 188). Quanto aos filhos de Herodes, todos $\hat{\epsilon}$ es terão nascido antes da ascensão de Augusto e de Marco Agripa, mas o nome dêste último começa a aparecer na dinastia herodiana com Agripa I, filho de Aristóbulo, e neto de Mariame. Nascido em 10 a. C., foi posterior ao advento de Marco Agripa, em cuja órbita Herodes entrou sòmente depois da batalha de Accio, em 31 a. C. Sem dúvida Herodes quis perpetuar no nome do neto a memória do amigo, falecido pouco antes do nascimento dêste (12 a. C.). Posteriormente o nome de Agripa tornar-se-á freqüente na família de Herodes.

262. - Por incrivel que pareça, foi, contudo, Herodes, rei dos judeus, um dos primeiros, e um dos mais zelosos fautores e promotores do culto de Augusto e de Roma, sujeito, naturalmente, às restrições que the impunha sua posição delicada de rei dos judeus. Já em 28 a. C. erigiu em Jerusalém, em honra de Augusto, um teatro, e um anfiteatro, instituindo ao mesmo tempo os jogos accíacos, a celebrar-se de quatro em quatro anos

\footnotetext{
(103). $\rightarrow$ Ignora-se a que porta do templo se refere José; cf. H. St. J. Thackeray 2, 196; G. Ricciotti, Flavio Giuseppe 2, 133.

(104).- - José costuma dizer César em lugar de Augusto, como outros escritores gregos e latinos. Parece evitar o nome por escrúpulo religioso (n. 260), enquanto Filón, judeu da Diáspora, o emprega sem mais; cf. J. Juster, ib. $\mathbf{3 4 3}^{1}$. O que traduzimos por templos de Augusto, leva, em José, o têrmo técnico de Kaisáreia.
} 
(A. 15, 8, $1 \S 268$ s) (105). Era esta a forma mais mitigada do culto imperial, mas não deixava, assim mesmo, de ser uma expressão do mesmo (106), e a única forma possível na capital do Judaismo. Em 27 a. C., inicia-se a reconstrução de Samaria, rebatizada em Sebasté, e constrói-se aí um templo em honra de Augusto (G. 1, 21, 2 § 403; cf. A. 15, 8, 5 § 298) (107). A Tôrre de Estratão, cuja reconstrução começou em 22 a. C., não só recebeu o nome de Cesaréia em honra de Augusto, mas foi ainda dotada de um templo de Augusto e de Roma, e instituiram-se aí jogos qüinqüenais em honra do mesmo imperador (G. $1,21,7 \S 414-$ $8 \S 415$; A. 15, 9, $6 \S 341 ; 16,5,1 \S 138$ ) (108), jogos que se celebraram pela primeira vez na 192a. Olimpiada, isto é, tomando ainda em conta os 12 anos da construção da cidade, em 10/9 a. C. (G. 1, 21, 8 § 415; A. 16, 5, 1 § 136) (109). Um terceiro templo de Augusto foi construído em Paneion (= Banyâs, n. 4), provàvelmente após esta região ter sido entregue a Herodes por Augusto, em 20 a. C. Note-se que êstes templos todos foram construídos em terrritórios de população prevalentemente pagã (110). Herodes desculpava-se perante os judeus, apelando para as ordens de Roma, e declarava a Augusto e aos romanos, que sacrificava os costumes nacionais ao anseio de honrá-los devidamente a êles (A. 15, 9, 5 §329s). Deve notar-se, contudo, que Herodes e seus sucessores, por meio dêstes compromissos, indesculpáveis aos olhos dos judeus, evitavam, todavia, aos mesmos judeus um sem número de vexações, que teriam sido inevitáveis, se Herodes ou

\footnotetext{
(105). - As accíadas mencionam-se expressamente em G. 1, 20, $4 \$ 398$, devenda entender-se os jogos accíacos, e não a éraĺaccíaca, 'W. Otto 69. nota. Sôbre a data, que outros fixam em 25 a. C. (J. Juster, ib. 3441), ver lb. 64 , texto e nota. Em Roma e em Nicópolis, celebravam-se ljogos qüinqüenais pára comemorar a vitória de Áccio, Augustó, Res Gestae, c. 9, 1; Suetônio, Auǵusstus 18; Cássio Dión, Historia Romana 53, 1, 4; L. Cerfaux-J. Tondriau, La culte des souverains (ver nota 96) 316s.

(106). - M.-J. Lagrange 179; F.-M. Abel 1, 363; J. Juster, ib. 345 .

(107). - Sôbre a data ver $W$. Otto 65 e 76. - J. Juster, ib. $341^{1}$. dá o ano de 25 a. C., citando $A .15,9,1 \S 299$, onde se menciona o ano 13 de Herodes. José ora data os anos de Herodes de 40, ora de 37 (cf. n. 171). Calculando de 40 a. C., chega-se a 27 a. C.

(108). - Cf. Filón, Legatio ad Gaium $38 \S 305 ;$ W. Otto 65 e 78. Em G. 1, 27, 7 $\$ 414$ só se fala no templo de Augusto, mas mencionam-se as estátuas de Augusto e de Roma, o que está de acôróo oom Suotônio, Augurstus 52: Templa... in nulla provincia nisi communi suo Romaeque nomine recepit. Cf. H. St. J. Thackeray 2, 194s. Pode concluir-se dai, qua também os outros ternplos de Augusto estivessem ao mesmo tempo consagrados a Roma.

(109). - Em A. fala-se errôneamente no décimo ano; cf. is, 9, $6 \$ 341 \mathrm{e}$ W. Otto 78 e 65; H. St. J. Thackeray 2, 197; L. Cerfaux-J. Tondriau, ib. 318.

(110): - W. Otto 65; cf. G. $1,21,4 \S 407$ e A. $15,9,5 \S 328$. Este templo figura nas moedas do tetrarca Filipe; of. !:A. Reifenberg, Moeday dos judew (trad. hebs.), Jerusalem 1947, 37s, nn. 39. 40. 42. 44; id., Ancient Hebrew Arts, New York 1950, 82, n. 4. Sôbre um quarto templo em Cánatha, na Batanéia, ver U. Holrmeister 45; E. Schürter 1, 43400.
} 
os romanos lhes aplicassem tôdas as exigências do culto imperial, o qual, afinal, era obrigatório para todos (111).

263. - A subserviência de Herodes manifestava-se, ainda, por meio de abundantes presentes, dados a Augusto e aos próceres romanos (112). Continuava, dêste modo, a política, adotada já em tempos de Marco Antônio, quando se tratava, todavia, mais de subôrno, do que de presentes pròpriamente ditos (n. 251). A série de contribuições inicia-se logo em Rodes, depois da restituição de Herodes ao trono (n. 205). Ainda no mesmo ano de 30 a. C., por ocasião da campanha de Otaviano no Egito, deu-lhe Herodes 800 talentos (n. 209), o que se poderá interpretar como contribuição de guerra, em seu caráter de rei aliado. Por ocasião de sua visita à Judéia, em 15 a. C., Marco Agripa e seus companheiros foram cumulados de muitos presentes (A. 16, 2, $2 \S 16)$. Em 13 a. C. seu filho Antípater levou consigo muitos presentes a Roma (A. 16, 3, 3 § 86; G. 1, 29, 2 573). Em 12 a .C., por ocasião do processo contra Alexandre e Aristóbulo em Aqüiléia, deu o rei a Augusto a soma de 300 talentos (A. 16, 4, $5 \S 128$ ), e lhe deixou igualmente uma soma imensa em seu testamento (113). Serviam para o mesmo fim, a demonstração de sua devoção para com Roma e o imperador, as inúmeras construções do rei em todo o Império, sobretudo as realizadas em Nicópolis, perto de Áccio, obra do próprio Augusto, e destinada a comemorar condignamente a vitória que lhe deu o império do mundo (A. $16,5,3 \S 147 ;$ G. $1,21,11 \S$ 425). Dêstes donativos, contudo, e das construções de Herodes no estrangeiro tornaremos a falar pormenorizadamente nos parágrafos dedicados às finanças do rei, e à sua política exterior.

264. - Uma última expressão da perfeita devoção de Herodes para com Roma, foram as diversas viagens oficiosas, por êle empreendidas, para encontrar-se com Augusto e Marco Agripa, no Oriente e em Roma. Augusto partira para o Oriente em 22 a. C., permaneceu na Grécia em 21, passou o inverno de $21 / 20$ e o de 20/19 em Samos, e aproveitou o ano de 20 para visitar as províncias da Asia. Marco Vipsânio Agripa, por sua vez,

\footnotetext{
(111). - J. Juster, ib. 340s: Au début du culte impérial, les Juifs eurent encore une autre chance: par lefur soumission aux Césars et leur adulation, les Hérodiens fournissaient des "équivalents" et ralcketaient, pour ainsi dire, be peuple d'Israël de plusieurs rites de ce culte. - Ver ib. $341^{1}$ um resirmo das atividades dos príncipes herodianos neste sentido.

(112). $\rightarrow$ Ver. U. Holameister $48 \mathrm{~s}$.

(113). - Engana-se U. Holzmeister 49, quando inclui a Saturnino, governador da Siria, entre os contemplados por Herodes. Foi seu filho Antípater quem tertou comprá-lo, G. $1,28,1 \S 554$. Vier, contudo, o que ficou dito no $n .252$.
} 
esteve na Asia de 23-21 a. C., fazendo as vêzes de vice-regente do Império no Oriente, e, mais uma vez, de 17-13 a. C. (114). Em 22-1 Herodes foi visitá-lo em Mitilene, na ilha de Lesbos (A. $15,10,2 \S 350$ ), e parece datar desta época a boa amizade, que, daí por diante, sempre o ligaria ao genro do imperador (115). Em 20 apresentou-se Herodes a Augusto na Síria, acompanhando-o depois até ao mar (A. 15, 10, $3 \S 354-360)$. Neste reencôntro, depois de 10 anos, com seu fautor imperial, a quem devia a confirmação no govêrno da Judéia (n. 204-208), 'foi agraciado com novo aumento de territórios (n. 267) e outros sinais de confiança (n. 268). Alguns anos depois, em 18 ou 17 a. C. (116), empreendeu viagem a Roma, para buscar seus filhos Alexandre e Aristóbulo (A. 16, 1, $2 \S 6$ ). Com efeito, em 23 a. C. (117), enviara os três filhos varões de Mariame à capital do império, para lá serem educados em casa de Asínio Polião (G. 1, 22, 2 $\S 435$; n. 251), ou, como se diz em outra passagem de José, para se apresentarem a César (A. 15, 10, 1: \$ 342). Um dêstes filhos, cujo nome não se conhece, faleceu em Roma (G. ib.). Não há motivo para lobrigar aqui mais uma expressão de servilismo, peculiar a Herodes, porque Augusto não só encorajava as alianças matrimoniais e de boa amizade entre as famílias dos reis aliados, mas ainda fazia educar os filhos de muitos dêles juntamente com os seus (118). Sem dúvida, o conhecimento pessoal do imperador e da côrte imperial, podia ser extremamente útil aos interessados, que ao mesmo tempo se enfronhavam no funcionamento das diversas engrenagens do Império (119) . Do mesmo modo Herodes Arquelau, Herodes Antipas e Filipe, os filhos sucessores do rei, educar-se-ão em Roma (G. 1, 31, $3 \S$ $602 ;$ A. $17,1,2 \S 20$ s), bem como seu neto Agrupa I e seu bisneto A.gripa II, e todos êles desfrutarão as vantagens das amizades ai entaboladas (n. 281).

265. - Durante o segundo estágio de Marco Agripa na Ásia, Herodes novamente o procurou, conseguindo que êle realizasse

\footnotetext{
(114). - B. Niese-E. Hohl 299; cf. A. 15, 10, $2 \S 350$; Suetônio, Auģustus 60.

(115). - W. Ottu 70. Natura!mente, trata-se de um exagêro da parte de José, quando afirma, que, na amizade de Augusto, Herodes vinha logo depois de Marco Agripa, na dêste logo depois de Augusto (G. 1, 20, $4 \S 400 ; A .15,10,3$ $\$ 361$ ); cf. W. Otto 55 . Isto não exclui que Agripa fôsse amicíssimo de Herodes (A. 15, $102, \S 350)$.

(116). - W. Otto 72 .

(117). - W. Otto 68; U. Holzmeister 37.

(118). - Suetônio, Augustus 48: Reges socios etiam inter semetipsos necessitudinibus mutuis junxit, promptissimus affinitatis cujusque atque amiditiae conciliator et fautor... ac plurimorum liberos et educavit simul cum suis et instituit.

(119). - W. Otto 68 .
} 
uma visita à Judéia, em 15 a. C. (120). Mostrou-lhe suas construções novas, Sebasté, Cesaréia, as fortalezas de Alexandreion, Herodium e,Hircânia, e conduziu-o até Jerusalém. Agripa aí ofereceu uma hecatombe no templo e um banquete ao povo, deixando simpatias gerais (A. 16, 2, $1 \S 12-15)$ (121). Uma terceira visita de Herodes, à frente de sua armada, a Marco Agripa, no Ponto, em 14 a .C., já foi mencionada (n. 244). Na volta acompanhou-o, por terra, pela Asia Menor, e, depois, por mar até 'à ilha de Samos. No trajeto teve o ensejo de mostrar sua liberalidade a favor de várias cidades da Ásia Menor, e o de interceder, junto de Agripa, a favor da cidade de Ilión, sucessora de Tróia, que havia incorrido as iras daquele (A. 16, 2, 2 \$16-23) (122). A viagem a Roma, realizada em 12 a. C., foi empreendida no interêsse do próprio Herodes (n. 237), enquanto uma terceira viagem sua à capital do Império, em 10-9 a. C., é problemática (123).

266. - Estas diversas expressões da devoção de Herodes para com Roma, e a pessoa de Augusto, foram largamente recompensadas. Não deixaram de influir nisto, naturalmente, as realizações do rei no cumprimento de seus deveres como rei aliado. Além dos territórios recebidos de Otaviano em Rodes, no ano de 30 a. C., por ocasião de sua restituição ao trono da Judéia (n. 211), mais duas vêzes foi recompensado pelo acréscimo de territórios novos. Vimos que Cleópatra, em 37-6 a. C., obtivera de Marco Antônio a execução de Lisânias, filho de Ptolomeu de Calcis, e a cessão de seus territórios (n. 189). Estes haviam sido, ao menos em parte, arrendados por um certo Zenodoro, que vivia de conluio com os bandidos da Traconítide (n. 236), para aumentar as próprias rendas (A. 15, 10,1 § 344; G. 1, 20, $4 \S 398$ ) (124). Estes bandidos infestavam a região de Damasco, perturbavam o comércio com o Mediterrâneo, e tornavam inseguras as rotas das caravanas da Transjordânia (A. 15, 10,1 §344; $17,2,1 \S 23$ (125). As reclamações dos habitantes de Damasco jun-

(120). - $w$. Otto 72 .

(121). - Cf. Filón, Legatio ad Gaium 37 \& 294-297; W. Otto 72

(122). $\rightarrow W$. Otto $72 \mathrm{~s}$. O último incidente, mencionado de passagem em $A$. ib. $\S 23$, 6 descrito mais longamente por Nicolau de Damasco, De Vita Sua, Fragmento 3 (ed. C. Müller, Fragmenta Historicorum Gracoorum III, Parisiis, 1883, 350). Júcia fitha de Augusto e mulher de Agripa, viajando para lión, quase pereceu, com seus companheiros, nas ondas do rio Escamandro. Os ilienses, desconhecendo sua chegady, foram multados por Agripa em 100.000 dracmas de prata. Nicolau e Herodes iconseguiram que fôssem perdoados.

(123). - Cf. A. 16, 9, $1 \S 271 ;$ G. $1,21,12 \S 427$. Admite a viagem E. Schürer 1, 414; nega $W$. Otto 122, nota; duvida U. Holzmeister 37.

(124). - Cf. W. Otto 69, nota; A. H. M. Jones 68 .

(125). - Cf. Estrabão, Geographica 16, 2, 20 (p. 756); W. 'Otto' 69. 
to de Varro, governador da Síria, e, por meio dêle, junto de Augusto, desencadearam uma ação de limpeza por parte das tropas romanas. O território, em 24-3 a. C., foi tirado a Zenodoro, e entregue a Herodes, juntamente com a Batanéia e a Auranítide, para prevenir que os bandidos novamente dêle usassem como base de operações contra Damasco. Roma, com efeito, devia estar lembrada da experiência que Herodes adquirira, desde cêdo, na luta contra os bandidos (nn. 103. 159. 161) (126) . As reclamações de Zenodoro em Roma não foram atendidas, nem as dos nabateus junto de Marco Agripa. A êles Zenodoro, pouco antes, havia cedido a Auranítide por 50 talentos ianuais. Naturalmente em todos êles Herodes granjeou novos inimigos. $\mathrm{Em}$ todo o caso, procedeu imediatamente contra os 'referidos bandidos, e deu socêgo às regiões por êles infestadas (G. 1, 20, 4 $\S 398$ s; A. $15,10,1$ § $343-2 \S 353 ; 17,2,2 \S 26)$ (127).

267. - Por ocasião da visita de Augusto à Síria, em 20 a. C. (n. 264), Herodes recebeu ainda novos acréscimos de territćrio. Tendo falecido, neste entretempo, o mencionado Zenodoro, recebeu êle mais algumas partes de sua tetrarquia, isto é, os territórios situados entre a Traconítide e a Galiléia (G. $1,20,4 \S 400)$, ou, mais exatamente, os territórios de Panéias e de Ulata, e as regiões adjacentes (A. 15, 10, 3 § 359s) (128). Desta forma, o reino de Herodes formava nestas regiões um todo compacto, e foi provàvelmente nesta ocasião que construiu, em Panéias, em sinal de gratidão, o templo já mencionado em bonra de Augusto (n. 262) (129). Esste, por sua vez, tinha motivos de sobejo para mostrar-se liberal para com Herodes, o qual dera provas suficientes para poder ser considerado guarda zeloso e enérgico dos interêsses do Império (130), o que não n impedia de adiantar ao mesmo tempo seus próprios interêsses.

268. - Vimos, por outro lado, que nesta mesma ocasião, em 20 a. C., o reino de Herodes sofreu certa diminuição, pela nomeação de seu irmão menor Feroras para tetrarca da Peréia, e procuramos adivinhar-lhe os motivos (n. 247-250). Esta diminuição, contudo, não impediu que se lhe concedessem outros

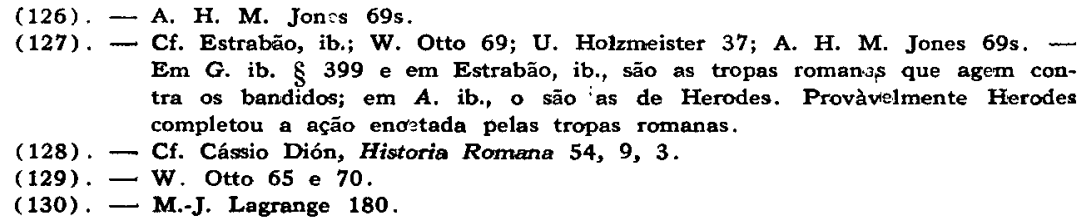


favores, uma vez que não havia motivos suficientes para obstacular-lhe a atividade como tal (131). Pelo contrário, estava inteiramente nos interêsses de Roma fortalecer sua posição. Assim, os funcionários da administração provincial da Síria receberam ordens para agir em tudo de entendimento com êle (G. 1, 20, 4 § 399; A. 15, 10, 3 § 360) (132). Os habitantes de Gádara, cidade doada por Augusto a Herodes em 30 a. C. (n. 211), ciosos de suas antigas liberdades, já se haviam queixado do rei junto de Marco Agripa, que os repelira. Entregara seus embaixadores a Herodes, que os soltara (A. 15, 10, 2 § 351). Instigados por Zenodoro (n. 266), tentaram novamente sua sorte junto do próprio Augusto, por ocasião da visita dêste à Síria, em 20 a. C. Sua recepção por parte do mesmo foi tal, que os delegados preferiram dar-se voluntàriamente a morte, a cair eventualmente nas mãos de Herodes (A. 15, 10, $3 \S 354-358$ ). Existem, dêste mesmo ano de 20 a. C., moedas de Gádara, com a efígie de Augusto, e a legenda: $\Sigma_{\epsilon} \beta a \sigma r o ́ s$, no que pode ver-se um sinal delicado da gratidão de Herodes (133).

269. - Outra expressão da estima imperial pode ver-se nos privilégios concedidos aos judeus da Diáspora, obtidos por intermédio de Herodes. Êste, por ocasião de sua visita a Marco Agripa na Asia, em 14 a. C. (n. 264), mandou apresentar-lhe, por intermédio de Nicolau de Damasco, os gravames dos judeus da Ásia (A. 16, 2, 3-5) . Agripa rejeitara as reclamações das cidades da Jônia contra os judeus, sob o pretexto de não lhe ser lícito introduzir inovações (A. 12, 3,2 § 126). Concedeu, pelo contrário, aos judeus a confirmação de seus privilégios, por causa de sua amizade para com Herodes, e em reconhecimento dos direitos, anteriormente adquiridos, dos judeus (A. 16, 2, $5 \$ 60$ ). Queixavam-se os judeus da Ásia, que se lhes vedava viver em conformidade com suas leis; que eram chamados a juízo em dias santos; que não se lhes permitia levar a Jerusalém o tributo anual devido ao templo; que eram obrigados a prestar o serviço

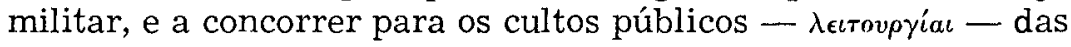

(131). - W. Otto 71 .
(132). - Ver a discussão destas passagens em W. Otto 71 , nota. Conforme José,
Herodes teria sido nomeado procurador - epitropos - de tôda a Síria.
Os autores em geral interpretam os textós da nomeação de Herodes para
conselheiro das finanças daquela província, o que se entende diante dos in-
terêsses comuns dia Síria e da Judéia; W. Otto 71 ; A. H. M. Jones 64 : Herod
was appointed financial adviser to the procurator of Syria; cf. U. Holz-
meister 37 G. Ricciotti 2 , 122 .
(133). - E. Schürer 3,102 W. Otto 71 . As moedas levam o ano 44 de Gádara $=20$
a. C. A éra de Gádara começou com Pompeu, em $64-63$ a. C. 690 ab U. C. 
cidades (A. 16, 2, 3-4) (134). Os pontos nevrágicos dos gravames contra os judeus eram, sobretudo, a faculdade de poder enviar livremente suas contribuições a Jerusalém, coisa contra a qual já Cícero reclamara em sua defesa de Lúcio Valério Flaco, propretor da Ásia, que se opusera ao transporte das contribuições (135). Marco Agripa decidiu, que os judeus pudessem viver conforme aos seus costumes; que não fôssem obrigados a comparecer em juízo nos dias de sábado, e que pudessem enviar livremente suas contribuições ao templo. Estes privilégios foram confirmados por Augusto (A. 12, 3, 2 § 125-127; 16, 2, 5 e $6,1-8)$. Parece, portanto, que, desta vez, se negou a dispensa do serviço militar, e a de contribuir para os cultos públicos (136). A identidade da decisão de Agripa a favor dos judeus da Cirenáica, sugere que Herodes se tenha empenhado igualmente a favor dêles (A. 16, 6, 1 e 5) (137). Examinaremos mais adiante, qual a relação entre o cargo de Herodes como rei dos judeus, e seus direitos'de interceder a favor dos judeus da Diáspora (n. 274-282).

270. - Aos favores imperiais concedidos a Herodes, e, em sua pessoa, aos judeus em geral, pode, sem dúvida, acrescentarse a instituição do sacrifício diário de duas ovelhas e um novilho, a ser oferecido no templo nas intenções do imperador, e do povo romano em geral. Filón afirma expressamente, que Éstes sacrifícios se faziam a expensas de Augusto (138). José, pelo contrário, que se ofereciam ex impensa communi omnium Judaeorum (139), o que faria dêles uma comum homenagem de todo o povo judaico (140). Ou José ignorava aquela circunstância, ou, então, depois de Augusto, os imperadores

\footnotetext{
(134). - Sôbre o sentido original de leitourtgéia vejam-se, por exemplo, H. Strathmann, em G. Kittek, Theologisches Wörterbuch zum Neuen Testament IV, Stuttgart 1942, 222-225; $\mathrm{Ph}$. Oppenheim, Institutiones Systematico-Historicae in Sacram Liturgiam VI, Taurini 1941, 1-7.

(135). - Cícero, Pro Flacco 28, 66-69; cf. J. Juster, ib. 370.

(136). - W. Otto 71 . Sôbre as concessöes romanas anteriores a favor dos judeu: ver J. Justen, ib. 1, 215-218; sôbre o șerviço militar, îb. 358 e 2, 274; sôbre as contribuiçōes para o templo, ib. 1, 377-385. - Sôbre a dispensa do serviço militar, a astráteia, dos judeus da Ásia por Dolabela, etc., ver $A$. $14,10,12 \S 225.13 \S 228$ e 230. 14 \$231s. $16 \S 234.18 \S 236$ s. $19 \S 240$.

(137). - - W. Otto 73. A forte colônia jứaica da Cirene é atestada, por exemplo, pelo Novo Testamento: Mt. 27, 32; Mc. 15, 21; Lo. 23, 26; Act. 2, 10; 6, 9; 10, 20; 13, 1. Não menos o é a da Ásia: Act. 2, 9; 6, 9 itc. Ambas possuiam suas sinagogas próprias e ceus representantes em Jerusalém: iAct. 6, 9.

(1:38). - Legatio ad Gaium $23 \S 156 ; 36 \S 291 ; 40 \$ 312$. Cf. Tertuliano, Apologeticum c. 26, 3 (PL 1, 493A): Judaea... cuius et Deum victimis, et templum donis, et gentem foederibus, aliquamdiu, Romani, honorastis.

(139). - Ap. 2, $6 \$ 77$, na parte conservada sòmente em latim (n. 51).

(140). $\longrightarrow$ J. Juster, ib. $1,347^{2}$.
} 
deixaram de pagar pessoalmente pelos sacrifícios que se ofereciam em seu nome. Pensa-se, sobretudo, em Tibério, o qual raão gostava de pagar pelas honras que se lhe tributavam (141). Conforme José, o sacrifício por César e pelo povo romano oferecia-se duas vêzes ao dia (G. $2,10,4 \S 197)$, mas não podemos definir mais, se as oferendas mencionadas se faziam duas vêzes por dia, ou se as vítimas se ofereciam em parte pela manhã, em parte pela tarde (142). Estes sacrifícios, aos quais podiam acrescentar-se sacrifícios extraordinários (143), e que se substituiam por orações nas sinagogas da Diáspora (144), eram a única forma possivel para os judeus, para oferecer uma espécie de compensação pelo culto imperial e o de Roma, que se praticava, obrigatòriamente, em tôdas as províncias do Império (145). Não se tratava, evidentemente, de sacrifícios oferecidos ao imperador e a Roma, mas de sacrifícios oferecidos a Deus pelo imperador e pelo povo romano; oferecidos no templo do Deus judaico, e não em um templo dedicado a Augusto e a Roma (146). Na Diáspora podiam os judeus dar mais uma prova de sua lealdade, dedicando suas sinagogas aos imperadores, como já o haviam feito, anteriormente, aos reis (147).

271. - Esstes sacrifícios pelo imperador e pelo povo romano continuaram a ser oferecidos até ao comêço da revolta de 66 d. C. (G. $2,10,4 \S 197$ e 17, 2 \$ 400-4 $\$ 417)$. Foi então que Eleá-

(141). J. Juster, ib. $1,347^{5}$.

(142). - Opinam pela segunda alternativa E. Schürer 3, 30398; H. St. J. Thackeray 2. 399.

(143). Conforme Filón, Legatio ad Gaium $45 \$ 356$, ofereceram-se sacrificios especiais na ascensāo de Calígula; qừndo recuperou-se de grave doença, e quando iniciou sua campanha na G:rmânia; cf. E. Schürer 3,304 .

(144). - Filón, In Flaccum $7 \$ 48-50$; cf. J. Juster, ib. 1, 346s, o qual tembra, ib. $347^{1}$, que, para os judetis'da Dłáspora, fora de Jerusalém, as orações equi:valiam aos sacrificios; cf. S. Justino, Dialogus cum Tryphone 117, 2 (PG 6, 745B-C)

(145). - J. Juster, ib. 1, 346s. Cf. V. Ehrenberg-A. H. M. Jones (ver n. 81) 7981 , n.:101 e 102, editos sôbre o culto imperiał, e ib. $78 \mathrm{~s}, \mathrm{n} .100$, e $82 \mathrm{~s}$, n. 105, o regulamento de Narbonne, relativo ao mesmo culto, etc.

(146). - J. Juster, ib. 1, 347. Caligula queixava-se desta distinção, que êle berm conhecia; Filón, Legatio ad Gaium $45 \$ 357 . \mathrm{Em} 2$ Mac. 6, 7 os judeus sầo forçados a participar dos sacrifícios oferecidos no aniversário de Antíoco IV.

(147). - J. Juster 1,348 e nota $4.412^{2}$. 4148. Ver a inscriçào da sinagoga de Athribis $=$ Benha em E. Gabba, Iscrizioni (ver n. 81) 24s: Em honra do rei Ptolomeu (VI?) e da rainha Cleópatra, Ptolomeu, filho de Epicides, comandiante das guardas, e os judeus de Athribis (dedicam) a casa de oração ao Deus Altíssimo. - Ver a mesma inscrição, e outras de Schedia = Kafr ed-Dauar (perto de Alexandria), Alexandria, Xenephyris = Kom el-Akhdar (perto do Damanhur) e Nitria = wadi Natrun, em J.-B. Frey, Corpus Inscriptionum Judaicarùm II, Città del Vaticano 1952, 370s, n. 1443. 366, n. 1440. 360, i. 1432, 367s, n. 1441 e 369, n. 1442. Ver ib. 1, LXXIII a relaçäo entrę os nomes das sinagogas romanas e seus patronos. 
zaro, filho do sumo-sacerdote Ananias e comandante da guarda do templo, propôs que não mais se aceitassem donativos ou sacrifícios de estrangeiros. Em conseqüência disto suspenderamse os sacrifícios pelo povo romano e pelo imperador (G. 2, 17, $2 \S 409)$. O partido dos moderados apela para a tradição, provando que todos seus antepassados haviam aceito sacrifícios, oferecidos em nome de estrangeiros (ib. $4 \S 417$ ), e afirma que os judeus seriam a única nação a não permitir a um estrangeiro o direito de oferecer sacrifícios (ib. $3 \$ 414$ ). Com efeito, já no tempo de Esdras, Dario havia tomado providências para se oferecerem sacrifícios em sua intenção, e na de seus filhos (Esd. 6, 9s), e Judas Macabeu instituira sacrifícios na intenção de De-

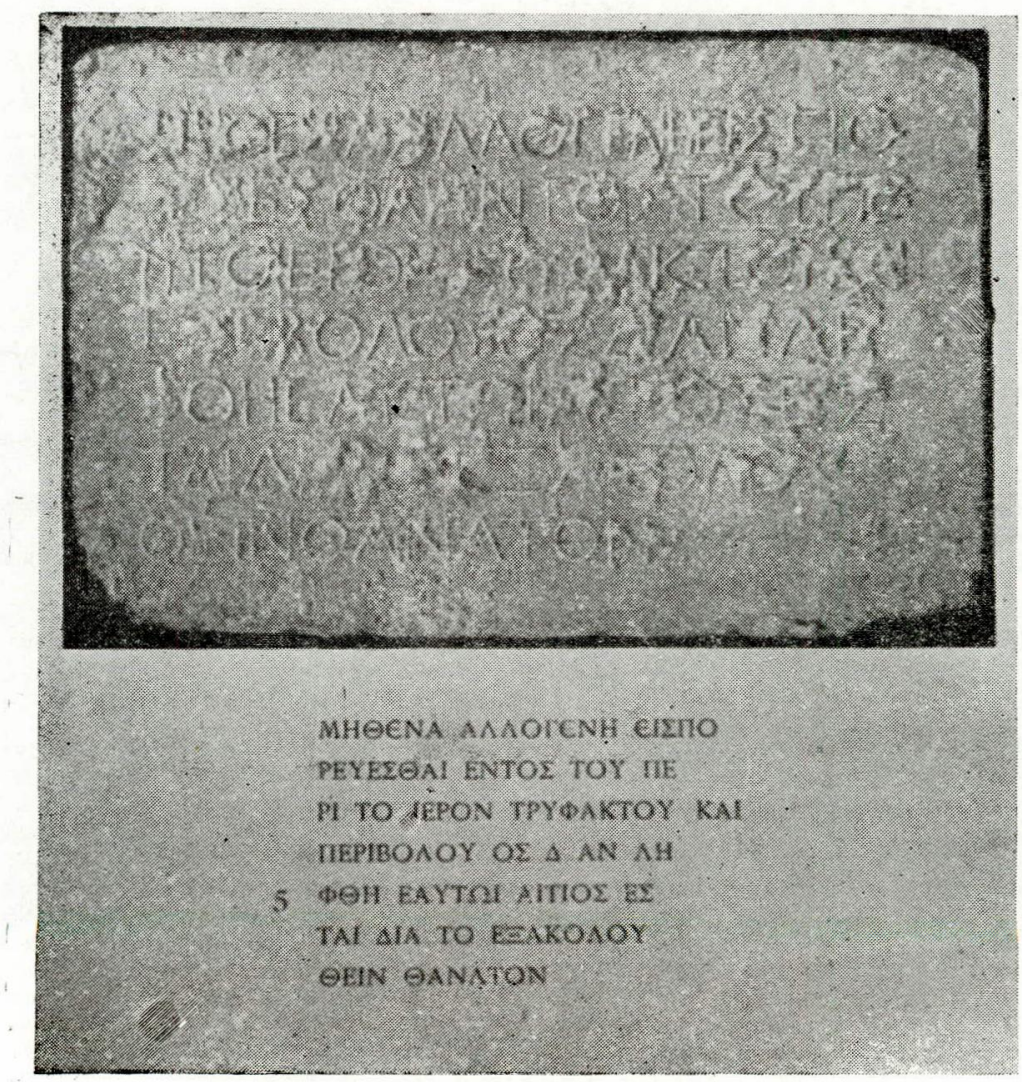

Inscrição grega do templo de Jerusalém.

(J.-B. Frey, Corpus Inscriptionum Judaicarum II, Città del Vaticano 1952, 329, n. 1400). 
métrio Sotér (1 Mac. 7, 33; A. 12, 10, 5 § 106) (148). Romanos ilustres, como Marco Agripa, e Lúcio Vitélio, governador da Síria, ofereceram sacrifícios no templo (A. 16, 2, 1 § 14; 18, 5, 3 § 122; cf. n. 265), como já Seleuco IV Filopator instituira uma fundação para o mesmo fim (2 Mac. 3, 3). A argumentação, contudo, dos moderados parece sugerir que ainda até à guerra de $66 \mathrm{~d}$. C. os imperadores pagavam pelos sacrifícios oferecidos em sua intenção, uma vez que a cessação dos sacrifícios se baseia na 'recusa de aceitar donativos e sacrifícios de estrangeiros. Em todo o caso, afirma José, que a suspensão dêstes sacrifícios eqüivaleu, pràticamente, a uma declaração de guerra (G. 2, 17, 2 § 409) . Tratava-se com efeito, nem mais nem menos, da suspensão do culto imperial obrigatório, nas formas aprovadas de modo especial para o caso particular da religião judaica, as únicas compatíveis com ela. Tratava-se, por conseguinte, da rejeição positiva da soberania romana, pela rejeição do culto devido a seu expoente máximo, a pessoa do imperador (149).

272. - A instituição do sacrifício diário por parte de Augusto não foi seu único ato relativo ao templo de Jerusalém, o lugar venerado por todo o mundo, e honrado desde os confins da terra pelos estrangeiros, que haviam ouvido sua fama (G. $4,4,3 \S 262$ ). Ouvimos falar, com efeito, de ofertas de Augusto e de Lívia ao templo, como, por exemplo, a de copas de vinho, que se fundiram durante a guerra de 66-70 d. C., com outras ofertas de estrangeiros, para custear as despesas da campanha (G. 5, 13, 6 § 562s). E' difícil imaginar, que tais vasos não fôssem de ouro ou de prata, os únicos metais compatíveis com a dignidade imperial. Semelhantes dádivas de estrangeiros não eram raras (G. 4, 3, $10 \S 181$; cf. $2,17,3 \S 413$ ), e vimos que o legado Caio Sósio só partiu de Jerusalém, conquistada por êle e Herodes em 37 a. C., depois de oferecer uma corôa de ouro a Deus (n. 168) (150). Sabemos, além disso, que Herodes, depois de reconstruir suntuosamente o templo de Jerusalém, mandou afixar na balaustrada, que cercava o átrio interior, inscrições, em grego e em latim, proibindo a entrada de estrangeiros, sob pena de morte (A. $15,11,5 \S 417$; G. 5,$5 ; 2 \S 193 ; 6,2,4 \S 124-$ 126) (151). Uma inscrição do gênero, em grego, foi encontrada

(148). - Cf. J. Juster, ib. 1, 3473; E. Schürer 3, 299-305. Já no Antigo Testamento recomendiava-se a oração pelas autoridades constituídas (Jer. 29,$7 ; B a r$. 1, 10s), e o mesmb faz a Mishnah (Aboth 3, 2).

(149). - J. Juster, ib. 1, 347; G. Ricciotti, Flavio Giuseppe 2, 264.

(150). - Outros exemplos em E. Schürer 3, 304s; J. Felten 1, 363.

(151). C. Filón, Legatio ad Gaium 31 \& 212 . Como exemplo da observância dêste preceito pode citar-se o do tribuno Neapolitano, que paga seus respeitos ao santuário de Deus do lugar de onde era permitido, G. $2,16,2 \S 341$. 
em 1871 (152). O fato de se falar em estrangeiros sem distinção

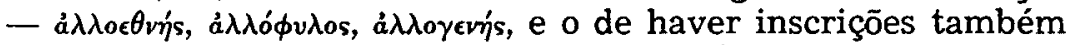
em latim, prova que a proibição era generalíssima, e que a sanção da pena de morte valia igualmente para os cidadãos romanos. Isto, por sua vez, só podia ter sentido, se autorizado por Roma, ciosíssima 'dos direitos de seus cidadãos. Ora, sabemos pela bôca do próprio imperador Tito, que êste direito verdadeiramente

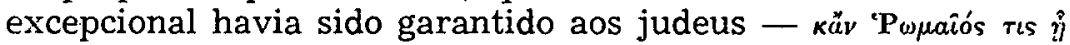
-, como também o direito de executarem êles mesmos aquela pena (G. 6, 2, 4 § 126 (153). Este privilégio singular só se explica satisfatòriamente como resultado da amizade entre Herodes e Augusto, e era êle tanto mais de apreciar, quanto sabemos que Augusto era defensor acérrimo dos direitos dos cidadãos romanos (154).

273. - Contudo, estas provas tôdas do que poderia interpretar-se como reverência para com o culto judaico por parte de Augusto, a instituição do sacrificio diário, a oferta de donativos, e a sanção da pena de morte para os profanadores da santidade do templo (155), não devem tomar-se como sinais de verda-

(152). - A lápide, de $0,58 \mathrm{~m}$ de altura, por 0,86 de largura e 0,37 de grossura, com letras de mais de $4 \mathrm{~cm}$ de altura, encontramse atualmente no museu de Istambul, um decalque no Louvre. Fragmentos de uma segunda lápide encontraram-se em 1936, e conservam-se em Jerusalém. O texto é o seguinte: Nenhum estrangeiro penetre no interior da balaustrada e do recinto que circundam o santuário. Quem fôr prêso, será êle mesmo a causa, se the seguir a morte'. - Estrangeiro diz-se allogenês, cf. Lc. 17, 18; $G$. 2i. 17, $4 \$ 417$ e os Setenta, quando José, ao falar da proibição, usa alloethnês A. 15, 11, $5 \S 417$, e allóphylas G. 5, 5, 2 \& 194 . - De entre as inúmeras reproduçōes, transcriçōes e traduçōes mencionamos: J. Juster, ib. 2, 142⿰; H. St. J. Thackeray 3, 258; F.-M. Abel 1, 376; U. Holzmeister 106; G. Ricciotti 400; A. H. M. Jones 108-109; V. Ehrenberg-A. H. M. Jones (ver n. 81) 88, n. 138, A. Deissmann, Licht vom Osten, 4. ed., Tübingen 1923, 62s: A. Reifenberg, Ancient Hebrew Arts, New York, 1950, 80; A. Parrot, Le Musé du Louvre e la Bible (Cahiers d'Archéologie Biblique 9), Neuchâtel-Paris 1957, 143-145; E. Gabba, Iscrizioni (ver n. 81) 8386, e Tavola 7 . Um facsímile da inscrição fragmentária encontra-se emı M. JoinLambert, Jerusalem, London 1958, 82. - Já Antíoco III, o Grande, proibira aos gentios 0 ingresso no interior do templo, sob pena de multa de 3.000 dracmas $(A, 12,3,4 \S 145 s)$.

(153). - J. Juster, ib. 2, 142 (contra E. Schirer 3, 188s; U. Holzmeister 106, o qual pensa sobretudo nos soldados romanos estacionados na Antônia); E. Gabbai, ib. 84s. - Em 80 a. C. O Senado decretou que 'os cidadãos romanos residentes em Quios ficassem sujeitos às leis lockis; cf. Corpus Inscriptionum Graecarum, n. 2222, citado por E. Schürer 3, $188^{150}$.

(154). - Numa inscrição de Cirene, de $7-4$ a. C., é censurado o governador rombano, por ter ıenviado, manietados, trếs cidadãos a Roma; cf. V. Ehrenberg-A. H. M. Jones (ver n. 81) 131, n. 311, II; H. Malcovati, Imperatoris Caesaris Augusti Operum Fragmenta, Augustae Taurinorum 1945, 62; J. Schmid, Zeit und Ort det pautinischen Gefandenschaftsbriefe, Freiburg i. Br. 1931. 169.

(155). - José diz, com efeito, que as inscrições em grego e em latim davam notícia da lej da santidade ou puridade do templo, G. 5, 5, 2 § 194 . 
deiro respeito para com a religião judaica, mas, antes, como resultados de considerações políticas, uma vez que Augusto, apesar de suas relações de amizade cordial com Herodes, sentia pessoalmente forte antipatia contra o judaismo (156). Este sentimento, como já dissemos (n. 71. 231), era compartilhado por muitos romanos daquela e de outras épocas, e provinha, em geral, de informações falsas, e do conhecimento insuficiente da religião judaica. Sabemos que Augusto desprezava os ritos das outras religiões em geral, e que elogiou seu neto Caio César, por não ter ido oferecer preces em Jerusalém, quando passou pela Judéia, de caminho do Egito para a Síria, em 1 a. C. (157). Se naquele ano ainda vivesse Herodes, certamente teria conseguido que o ilustre viajante subisse a Jerusalém, como conseguira que a visitasse Marco Agripa, 14 anos antes (n. 265). O fato, contudo, como tal, prova que tais visitas de cortesia e de piedade cosmopolita já eram de praxe, e que a visita ao santuário de Jerusalém se tornara obrigatória para os turistas de então (158) . Êstes, contudo, não devem confundir-se com os prosélitos, isto é, com aquêles que haviam abraçado, integralmente, ou em parte, a religião judaica, como os conhecemos, por exemplo, pelo Novo Testamento (159) .

274. - III. Herodes, rei dos judeus. - Tendo examinado a posição jurídica de Herodes como rei aliado de Roma, os limites e a extensão de seu poder, bem como suas relações com a pessoa de Augusto, não é sem interêsse para a nossa história, perguntarmos qual o título exato que lhe competia como rei da Judéia, uma vez que o título de um príncipe, ou de um rei, pode dar uma idéia, mais ou menos exata, das atribuições que lhe competiam (160). Como ficou visto, êle mesmo, em suas moedas, con-

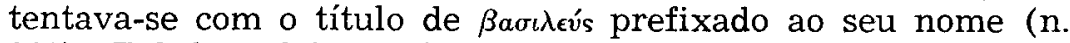
260). Tal é também o título que, em geral, lhe davam no es-

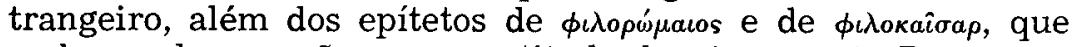
nada revelam, a não ser sua atitude devota perante Roma, e a pessoa de Augusto (n. 259). Seus descendentes, Berenice e Agripa II, o designam, em sua inscrição de Beirute, como Rex He(156). - E. Echürer 3, 304; U. Holzmeister 38.

(157). - Suetônio, Augustus 93: Peregrinarum aaerimoniarum sicut veteres ac praeceptas reverentissime coluit, ita caeteras contemptui habuit... non modo in peragranda Aegypto paulo deflectere ad visendum Apin supersedit, sed et Gaium nepotem, quod Judaeam pratervehens apud Hierosolyma non supplicasset, conlaudavit.

(158). - E. Schürer 3, 302; cf. G. 4, 5, $2 \S 324$, onde se fala de visitantes de todo o mundo.

(159). - Ver os gregos que querem aproximar-se de Jesus Jo. 12, 20; os prosélitos em Act. 2, 10s; o eunuco etíope ib. 8, 27, etc.

(160). - Ver E. Bikerman 4-7 sôbre os títulos usados pelos selêucidas, e a relação entre títulos e reino. 
rodes, e um súdito seu ainda lhe dá o título de kúplos (161). Não havendo, naquela época, outro rei de nome Herodes, não havia perigo de confusão, e, por conseguinte, não havia necessidade de ulterior determinação (162). Por isto mesmo vemos que os autores gregos e latinos em geral o mencionam simplesmente como Herodes ou Herodes, o rei. O contexto, todavia, explica suficientemente que se trata de nosso Herodes, o primeiro rei dêste nome, comumente designado como o Grande (163).

275. - Diz, contudo, José, que Marco Antônio, por ocasião da fuga de Herodes para Roma, resolveu, sem mais, nomeá-lo

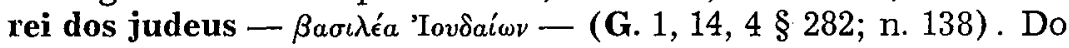
mesmo modo Hircano II havia sido nomeado etnarca dos judeus

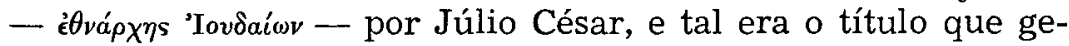
ralmente se lhe dava (164). Vemos ainda pelos Evangelhos, que os soldados de Pilatos, ao parodiar o cerimonial régio com a pessoa de Jesus, dão-lhe o título de rei dos judeus (MIt. 27, 29; Mc. 15, 18; Jo. 19, 3), e que Pilatos o interroga, se êle é o rei dos judeus !(Mt. 27, 11; Mc. 15, 2. 9; Lc. 23, 3; Jo. 18, 33. 39), mandando igualmente pregar êste título na cruz, sem incomodar-se com a susceptibilidade judaica (Mt. 27, 37; Mc. 15, 26; Lc. 23, $38 ;$ Jo. 19, 19-22). Podemos supor que a soldadesca romana aproreitou a ocasião, para, na pessoa de Jesus insultar o povo judaicc todo (165), o que se torna tanto mais verossímil, quanto sabemos que as tropas auxiliares da Judéia se recrutavam em grande parte entre os samaritanos e os sírios (166). Pilatos, por sua vez, falava e agia do ponto de vista do governador roma-

\footnotetext{
(161). - Ver a inscrição de Beirute em E. Gabba, Iscrizioni (ver nota 147) 102; St. Perowne, The Later Herods, London 1958, 116-117. A segunda inscrição, posta por Obáisato, fitho de Seodo, provêm da base de uma estátua de Herodes, e foi encontrada em Seeia = Siâ, na Batanéia, cf. E. Schürer 1, 43400; E. Gabba, ib. 39; U. Holzmeister 50.

(162). - Em época posterior tamos seu neto, Herodes, rei de Calcia. Êste, aliás, em suas moedas, também só se chama Basiléys Herôdês, ou ajunta ao nome o epíteto de Philokláudios, cf. A. Reifenberg, Moedas dos judeus (trad. hebr.), Jerusalém 1947, 42 n. 68-70.

(163). $\rightarrow$ Ver, por exemplo, Estrabão, Geographica 16, 2, 34 e 46; Herodes; Horácio, Epistolarum 1. 2, Epístola 2, 183: Herodis palmetis pinguibus; Tácito, Historiarum 5, 9 e 11: Herodes; Cássio Dión, Historia Romana 49, 22, 6; $54,9,3$, e 59, 8 2: Herodes; Plínio, o Velho, Naturalis Historia 5, 13, 69: Herodes rex, etv.; Plutarco, Antonius 72, 2: Herodes, o rei, mas ib. 61, 2 e 71, 1: Herodes, o judeu.

(164). - Cf. A. 14, 8, $5 \S 151$ (Atenas). 10, $2 \S 191.194 .5 \S 200.7 \S 211$ (César). $12 \cdot \S 226$ (Dolabela). 12,4\$317 (Marco Antônio).

(165). - Cf. J. Klausner, Jesus von Nazareth, 3. ed., Jerusalém 1952, 487.

(166). - Cf. U. Holzmeister 97; J. Pick1, Messiasköniǵ Jesus, München 1935, 134. 141.
} 
no, ocupado, no momento, em examinar e ridicularizar o que lhe pareciam ser aspirações políticas descabidas e puníveis (167). Em todo o caso, vemos que o título de rei dos judeus era aquêle, que espontâneamente se apresentava àquêles que queriam designar a pessoa de quem exercia o poder régio na Judéia, ou a daquele, a quem se atribuia o direito de exercê-lo, como os magos do Oriente simplesmente perguntaram pelo recém-nascido rei dos judeus (Mt. 2, 2) . De fato, podia o próprio Herodes ser designado como rex Judaeorum (168).

276. - Era necessário examinar o título provável que competia a Herodes, porque se trata de saber, se o título de rei dos judeus, de preferência a rei da Judéia (169), implicava que a êle competia jurisdição sôbre os judeus em geral, incluindo, por conseguinte, os judeus da Diáspora, ou se êle se referia apenas aos judeus da Palestina, isto é, da 'Judéia em sentido largo. A razão desta pergunta é o título e a posição de Hircano II, cujo sucessor imediato Herodes pretendia ser. Vimos, com efeito, que Hircano havia sido nomeado etnarca dos judeus, e era con-

(167). - J. Klausner, ib. 485s.

(168). - Macróbio, Saturnalium 2, 4, 11:... inter pueros, quos in Syria Herodes rex Judaeorum intra bimatum jussit interfici.

(169). - Herodes é chamado rei da Judéia - basiléys tês Jourdaéas - em Lc. 1, 5, onde naturalmente, a Judéia 'deve entender-se em sentido largo; cf. M.-J. Lagrange, Evangile selon saint Luc, 2. led., Paris 1921, 9. Aquêles que defendem a teoria de que São Lucas se serviu, na composiçäo da 'hilstótia da infância de Jesus (cc. 1-2), de fontes escritas, que, por sua vez, eram traduçōes gregas de'originais hebrałcos, explicam as palavras tês Joundaías como acréscimo do tradutor grego, destinado a explicar a seus leitores cristãos de origem grega, de que rej, de nome :Herodes, se tratava. Parł os judeus palestinenses bastava dizer rei Herodes; of. P. Gächter, Maria im Erdenleben, (2. ed. Innsbruck 1954, 28s; R. Laurentin, Structure ot théologie de Luc I-II, Paris 1957, 13. A descoberta te textos originais hebraicos em Qumran prova o conhecimento da lingua em largo's ambientes do povo, apesar de se falar então em geral o aramaico-palestinense, como provarm, por exemplo, as palavras de Jesus, conservadus nos Evangethos. Em Mt. 2, 1 e 3, cujo texto original, conforme a tradição antiga, fơ o hebraico-aramaico, diz-se apenas: nos 'dias do rei Herodes, e: o rei Herodes, como também na literatura rabínica êle é .mencionado apenas como o rei Herodes (LevRabba 35). Era necessário, em tempos posteriores, juntar o qualificativo de rei, porque houve outros Herodes (que não o foram, uma vez que dificilmente poderia haver confusão com Herodes, rei de Calcis. Em todo o caso, parece $L a, 1,5$ ser o único texto independente, em que Herodes é chamado rei da Judéia. S. Epifânio, Adversưs Haereses, Hzeresis 30, 13 (PG 41, 428D), cita o príncipio 'do Evangelho dos Doze, evangelho apócrifo de origem ebionita, que começa exatamente como Lc. 1,5 , e deve depender desta passagem; icf. A. de Santos Overo, Los Evangelios apócrifos, Madrid 1956, 54. Para ilustrar a diversidade dos títulos comparem-se os Atas de Pilatos, Prólogo, onde Herodes Antipas é chamado rei (?) tês Galitáaias, e uma carta apócrifa do mesmo Herodes a Pôncio Pilatos, onde êle se intitula tetraroa Galilaíon; ef. A. de Santos Otero, ib. 428 e 518. 
siderado e tratado como tal (n. 275). Por ordem de César, os judeus obtêm do Senado um tratado de amizade e de aliança, e enviam-se cartas às cidades autônomas e aos reis a favor de seu país e de seus portos, e a fim de que não sofram alguma in-

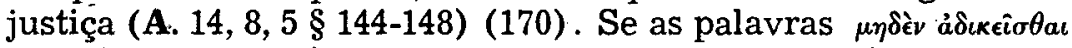
se referem ao país e aos portos dos judeus, contêm elas um aviso às cidades e aos reis, para não molestarem os judeus em sua própria terra; caso contrário, só podem referir-se aos judeus da Diáspora (171). José reproduz, ainda, uma carta dos magistrados de Laodicéia da Frígia, na qual se mostram informados das ordens de Roma, de que ninguém pode dar ordens aos judeus, e de que a ninguém é lícito, em seu território, fazer-lhes alguma injustiça (A. 14, 10, $20 \S 241$ s) (172). Enfim, Hircano II, como pontífice e etnarca, é reconhecido por César como protetor de todos os judeus, que sofrerem alguma injustiça -

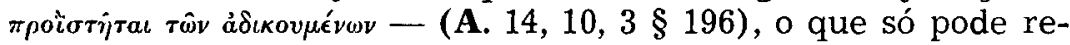
ferir-se aos judeus da Diáspora. Os diversos privilégios concedidos aos judeus por César, foram confirmados em bloco por Augusto, e para os judeus de todo o Império (A. 16, 6, 2-3) (173).

277. - Em conseqüência desta sua posição, vemos que Hircano II interveio, de fato, e por diversas vêzes, a favor dos judeus da Diáspora, bem como a favor dos judeus, diretamente súditos seus. Em 44-3 a. C. interveio, junto de Dolabela (n. 116), a favor dos judeus da Asia, pedindo que fôssem dispensados do serviço militar, e que lhes fôsse permitido manter os costumes tradicionais, e viver de acôrdo com êles. O pedido foi deferido, e as ordens de Dolabela foram comunicadas às cidades da Asia (A. 14, 10, $11 \S 123-12 \S 127$ ). Se a carta dos laodicenos, já mencionada (n. 276), se refere, de fato, ao tempo de Hircano II, é ela o resultado de uma intervenção sua junto do governador romano da Asia, o qual também mandou ordens idênticas ao povo de Trales. Em todo o caso, os magistrados

\footnotetext{
(170). - H. St. J. Thackeray 7, 524 refere êste decreto ao tempo de Simäo Macabeu, em 139 a. C.; cf. 1 Mac. 15, 16-21, onde igualmente se menciona um cônsul de nome Lúcio, e se enumeram as cidades e os reis que receberam cartas dos ramanos, ib. 22-24. - J. Juster, ib. 1, $216^{3}$ cita o decreto como sendo do tempo de Hircano II. Der qualquer modo, os outros textos por ciष:r säo bastante expressivos sôbre a matéria que nos interessa.

(171). - Cf. J. Juster, ib. 1, 216 .

(172). - Discute-se, novamente, se os documentos em apreço se referem aos tempos de João Hircano (134-104), ou aos de Hircano Ir; cf. H. St. J. Thackeray $7,577 \mathrm{~s} ; \mathrm{J}$. Juster, ib. 1, $146^{7}$ e $216^{3}$. No primeiro caso os privilégios concedidos a Hircano II são apenas a confirmação de privllégios anteriores

(173). - Cf. J. Juster, ib. 1, 2163.
} 
de Laodicéia prometem acatar as ordens recebidas (A. 14, 10, $20 § 241-243)$ (174). Hircano interveio, igualmente, junto de Marco Antônio, pedindo que se restituisse a liberdade aos judeus aprisionados e vendidos por Cássio Longino (n. 114. 125), e que se devolvessem a êle os territórios judaicos conquistados por Marión de Tiro (n. 120s. 125). Ambos os pedidos foram atendidos pelo triúnviro (A. $14,12,2 \S 304-6 \S 332 ; n$. 125). Diante do caráter indolente de Hircano II (n. 12. 102), não é improvável, que sua intervenção em todos êstes casos, se devesse à energia, primeiro, de Antípater, e depois, de seus filhos, sobretudo de Herodes, o qual, em todo o caso, continuou esta mesma política de intervenção a favor dos judeus da Diáspora, e obteve, igualmente, privilégios a favor dos judeus diretamente súditos seus. Esta política é seguida, ainda, por seus descendentes, herdeiros, ou não, do govêrno de tôda a Judéia.

278. - Vemos, com efeito, que Herodes, em 14 a. C., por ocasião de sua visita a Marco Agripa (n. 252), interveio a favor dos judeus da Ásia Menor, obtendo para êles os privilégios reclamados, em parte como conseqüência de sua amizade com o chefe romano, em parte em reconhecimento dos direitos anteriormente adquiridos dos judeus (A. 16, 2, $5 \S 60 ; n$. 265). A identidade das decisões do mesmo Agripa a favor dos judeus da Cirenaica (A. 16, 6, 1 e 5), sugere, como dissemos, que elas se devam igualmente à intervenção de Herodes (n. 255). À mesma amizade do rei com Augusto e Marco Agripa, e à sua posição de rei dos judeus, devem atribuir-se também os outros privilégios concedidos ao povo judaico já analisados (n. 270-273). Agripa I, arriscando a própria vida, interveio junto de Calígula a favor dos judeus, numa das piores crises da história dêstes, quando aquêle imperador queria que se colocasse sua estátua no próprio templo de Jerusalém (A. 18, 8, 3-8). Interveio, ainda, junto de Públio Petrônio, governador da Síria, a favor dos judeus de Dora (= el-Burdj), cidade fora de sua jurisdição, onde alguns jovens haviam colocado uma estátua de Cláudio na sinagoga local. Petrônio prontamente tomou as medidas necessárias (A. 19, 6, 3s). Juntamente com seu irmão Herodes, rei de Calcis, Agripa interveio, ainda, junto de Cláudio, a favor dos judeus de Alexandria (A. 19, 5, 2 § 279 e $3 \S 288$ ).

279. - Os príncipes herodianos sempre continuaram a interessar-se ativamente pelos negócios dos judeus, e as autori-

(174). - Trales é menciona ib. $\S 242$, cf. J. Juster, ib. $1,216^{3}$. 
dades romanas timbravam em aceder a seus pedidos, e em consultá-lós a respeito das questões judaicas (175). Sua deferência chegou ao ponto de conceder a nomeação dos sumos-sacerdotes, e a superintendência do templo de Jerusalém aos reis herodianos, que não reinavam na Judéia pròpriamente dita, como Agripa II, e nem mesmo na Palestina, como Herodes de Calcis. Se esta medida, aos olhos dos judeus, nada tirava do caráter odioso da ingerência de leigos e de descendentes de estrangeiros nos negócios do templo, e na sucessão dos pontífices, era ela, aos olhos dos romanos, uma concessão enorme, quando durante decênios, de 6 a $37 \mathrm{~d}$. C., os procuradores romanos da Judéia, e os governadores da Síria, se haviam arrogado aquêles direitos, imitando os precedentes inaugurados por Herodes e Arquelau (n. 180 (176).

280. - E', contudo, difícil dizer, até que ponto se devem atribuir as concessões romanas à posição oficial de Herodes e de seus descendentes, e não, antes, às suas relações de amizade com os diversos imperadores romanos. Quanto às primeiras, temos as duas nomeações de Herodes, confirmadas por senatusconsultos, a primeira de 40 a. C., por proposta de Marco Antônio e com o consentimento de Otaviano (n. 138s); a segunda, de 30 a. C., por restituição por parte de Otaviano (n. 205). Na nomeação de Arquelau, em 4 a. C., por nomeação de Augusto (G. $2,6,3 \S 93 ; \mathbf{A} .17,11,4 \S 317$ ), deve ter-se dado a renovação do foedus non aequum, por meio de um senatus-consulto, de que, todavia, não se fala (177). Cláudio contraiu aliança formal com Agripa I em pleno fôro de Roma (A. 19, 5, $1 \S 275$ ), proclamada por meio de um edito, e perpetuada em placas de bronze, depositadas no Capitólio (G. 2, 11, 5 § 215s). Agripa, por sua vez, perpetuou em suas moedas a lembrança do pacto de amizade e de aliança com Roma, como também os sacrifícios oferecidos na ocasião (178) . Na mesma ocasião, Herodes, seu irmão, foi nomeado rei de Calcis (G. 2, 11, $5 \S 217$ ), obtendo ainda do mesmo Cláudio a superintendência do templo e do sumo-sacerdócio por oca-

\footnotetext{
(175). - Ver o convite do procurador Felix para Agripa II e Berenice assistirem à defesa de Sāo Paulo Act. 25, 13-26, 32, O mesmo Agripa empenhou-se sèriamente em dissurdir os judeus, em 66 d. C., a revolta contra Roma, G. 2, $16,3 \S 342-17,1 \S 407,17,4 \S 417-421$ e $19,13 \S 523-526$, etc. Conseguira igualmenta, que Cláuđio autorizassa os judeus a 'conservar em seu poder as vestes do sumo-sacerdote, $A .20,1,1$.

(176). 一 U. Holzmeister 109.

(177). - Cf. J. Juster, ib. $217^{2}$.

(178). - A. Reifenberg, Moedas das judeus (trad. hebr.), Jerusalérn 1947, 41, n. 63.
} 
sião da morte de Agripa (A. 20, 1, 3 § 10) (179). Em todos êstes casos, porém, não possuímos os textos das nomeações e dos tratados; e não sabemos se êles continham cláusulas a respeito dos judeus da Diáspora. Se podemos supor que as cláusulas do tratado entre César e Hircano II (n. 276) serviram de modêlo aos tratados posteriores, podemos responder na afirmativa (180).

281. - Acontece, porém, que todos êstes príncipes herodianos, à exceção talvez de Arquelau e de Herodes de Calcis, sôbre os quais não estamos tão bem informados, mantinham relações de amizade pessoal com os imperadores e outros chefes romanos. Já mencionamos os laços de amizade que uniam Herodes a Augusto, a Marco Agripa e a Asínio Polião (n. 232. 251). Augusto a ela se refere (A. 16, 9, $3 \S 290$ ), e o mesmo faz Marco Agripa em sua decisão a favor dos judeus da Ásia Menor (A. 16, 2, 5§60). Herodes Antipas, sucessor de Herodes na Galiléia e na Peréia, era amicíssimo de Tibério (A. 18, 2, 3 § 36; cf. 5, $1, \S 114 ;$ G. $2,9,5 \S 178$ ), amizade que devia datar do tempo em que fôra educado em Roma, juntamente com seus irmãos Arquelau e Filipe (A. 17, 1, $3 \S 20$; G. $1,31,1 \S 602$ ). Agripa I fôra educado com Cláudio, e tornou-se amigo íntimo dêste e de Calígula, o que lhe valeu sua carreira, e o pôs em condições de interceder por diversas vêzes a favor dos judeus (n. 278). Cláudio invoca a amizade de Agripa e de Herodes de Calcis em seu decreto a faror dos judeus de Alexandria (A. 19, 5, $3 \S 279$ ), a de Agripa II: e de Aristóbulo, filho e sucessor de Herodes de Calcis, em seu decreto a respeito do ornato pontifical (A. 20,1,2 § 13; cf. 1, $1 \S 2$ ) (1.81). O mesmo Agripa II não era menos cotado pelos romanos de que seus predecessores. Em todo o caso, o menos que se pode dizer de todos êstes príncipes herodianos, descendentes embora do idumeu e semi-judeu Herodes (n. 89), é que suas intervenções a favor dos judeus junto de seus amigos romanos, intervenções que, na maioria dos casos, partiam de um interêsse sincero pelo povo judaico, justificam em grande parte a sua existência.

282. - Por outro lado, as relações de amizade de' todos êles com os chefes romanos, dificulta a determinação exata de sua posição com relação aos judeus da Diáspora. Ainda que seus

(179). 一 Cf. J. Juster, ib. $217^{2}$; U. Holzmeister 133.

(180). - Cf. J. Juster, ib. $217^{3}$.

(181). - Filón, Legatio ad Gaium $37 \S 296$; of. J. Juster, ib. 1, 2174. O mesmo Aristóbulo foi posteriormente nomeado roi da Armênia Menor por Nero, $G$, $2,13,2 \S 252$. 
títulos de reis ou etnarcas dos judeus incluíssem, porventura, certos direitos de protetorado sôbre os judeus da Diáspora, é muito provável que, em suas intervenções junto das autoridades romanas, mais valessem suas relaçōes de amizade com os diversos imperadores romanos, e a boa vontade dêstes, do que eventuais direitos, que lhes haviam sido cedidos, sempre como resultado daquela mesma boa vontade imperial, a favor dos judeus da Diáspora. E' possível, até, que em suas relações oficiais com as autoridades romanas, de ambas as partes não se cogitasse dos direitos, que eventualmente lhes competiam. Como quer que fôsse, é certo que os judeus da Diáspora, quer os herodianos tivessem, ou não, direitos protetorais sôbre êles, se sentiam em geral uma coisa só com seus irmãos da Palestina, e que, por vêzes, faziam sentir o pêso de sua opinião a favor ou contra os príncipes herodianos, e geralmente a favor de seus irmãos da Judéia, como veremos em seus respectivos lugares.

(Continua no próximo número).

\section{JOÃO MEHLMANN O.S.B.}

da Pontifícia Universidade Católica de São Paulo e professorvisitante da Faculdade de Filosofia, Ciências e Letras da Universidade de Sáo Paulo. 